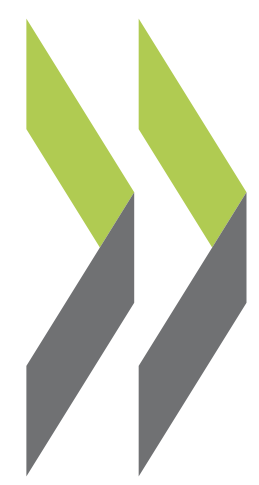

OECD Labour Market and Social Policy Occasional Papers No. 14

\title{
Measurement of Low Incomes and Poverty in A Perspective of International Comparisons
}



OCCASIONAL PAPERS

No. 14

MEASUREMENT OF LOW INCOMES AND POVERTY IN A PERSPECTIVE OF INTERNATIONAL COMPARISONS By

Michael F. Förster 


\title{
DIRECTORATE FOR EDUCATION, EMPLOYMENT, LABOUR AND SOCIAL AFFAIRS
}

\section{OCCASIONAL PAPERS}

This series is designed to make available to a wider readership selected labour market and social policy studies prepared for use within the OECD. Authorship is usually collective, but principal writers are named. The papers are generally available only in their original language -- English or French -- with a summary in the other.

Comment on the series is welcome, and should be sent to the Directorate for Education, Employment, Labour and Social Affairs, 2, rue André-Pascal, 75775 PARIS CEDEX 16, France. Additional, limited copies are available on request.

\section{Applications for permission to reproduce or translate all or part of this material should be made to:}

\author{
Head of Publications Service \\ OECD \\ 2 rue André-Pascal \\ 75775 Paris, Cedex 16 \\ France
}

Copyright OECD, 1994 


\section{SUMMARY}

During the past two decades, issues such as insufficient resources among particular populations, relative and absolute low incomes and poverty have occupied a prominent place in social policy research in many OECD countries. However, many different concepts have been used in the literature to define and measure 'low income' or 'poverty' across and within Member countries. This paper analyses alternative approaches to quantifying these concepts for the explicit purpose of international comparisons. It uses micro data sets on income from the Luxembourg Income Study for 13 OECD countries, for the mid- to the end of the 1980s, to illustrate the issues.

In Chapter II, the three main approaches used in the literature for defining low income and poverty - the absolute, relative and subjective approach - are discussed in detail. Chapter III discusses ways to adjust disposable income for family size and presents sensitivity tests using different equivalence scales. Chapter IV presents more comprehensive poverty indicators, in particular the Sen index which allows for the decomposition of poverty into incidence, intensity and distribution of low incomes. Chapter $\mathrm{V}$ considers the role of public transfers in alleviating poverty and applies the Sen index for an analysis of the net impact of taxes and transfers on poverty among non-elderly families, families with many children, single-parent families and children. The final chapter presents the main conclusions.

Michael Förster is an economist, attached to the OECD Directorate for Education, Employment, Labour and Social Affairs.

\section{RESUMÉ}

Durant ces quelque vingt dernières années, des questions telles que l'insuffisance de ressources de certaines catégories de populations, les bas revenus relatifs ou absolus, et la pauvreté ont occupé une place importante dans la recherche en matière de politiques sociales. Or, il existe une vaste palette de concepts différents utilisés pour définir et mesurer 'bas revenus' et 'pauvreté' d'un pays de l'OCDE à l'autre. Cette étude analyse des approches susceptibles d'appréhender ces phénomènes dans un cadre de comparaison internationale. Pour ce faire, elle utilise des données micro-économiques sur les revenus de la "Luxembourg Income Study" pour treize pays Membres, couvrant la période du milieu jusqu'à la fin des années 80 .

Le chapitre II discute en détail les trois concepts principaux servant à définir les bas revenus et la pauvreté: les approches dites absolue, relative et subjective. Le chapitre III décrit différentes méthodes d'ajustement du revenu disponible selon la taille de la famille et présente des tests de sensibilité en utilisant des échelles d'équivalence différentes. Le chapitre IV présente des indicateurs de pauvreté plus complets, en particulier l'indice de Sen qui permet une décomposition de la pauvreté en 'incidence', 'intensité' et 'distribution' de bas revenus. Le chapitre $\mathrm{V}$ examine le rôle que jouent les transferts publics dans la réduction de la pauvreté et applique l'indice de Sen à une analyse de l'impact net des impôts et des transferts sur la pauvreté parmi des familles encore jeunes, des familles nombreuses, des familles monoparentales, et des enfants. Le dernier chapitre présente les conclusions générales.

Michael Förster, l'auteur, est économiste auprès de la Direction de l'Éducation, de l'Emploi, du Travail et des Affaires sociales de l'OCDE. 
TABLE OF CONTENTS

I. INTRODUCTION ............................................................................................................................................ 6

II. DIFFERENT APPROACHES TO DEFINING LOW INCOME AND POVERTY ............................................ 7

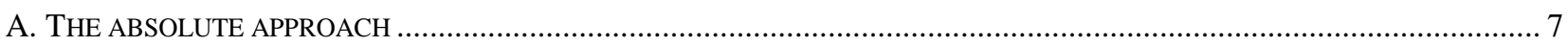

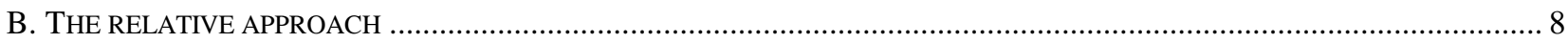

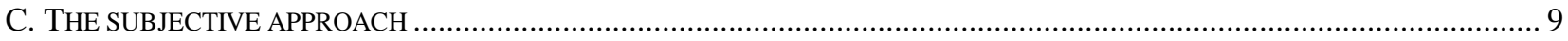

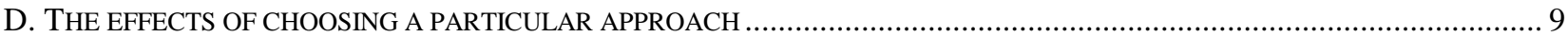

III. HOW TO ADJUST FAMILY INCOME: EQUIVALENCE SCALES AND THE REFERENCE

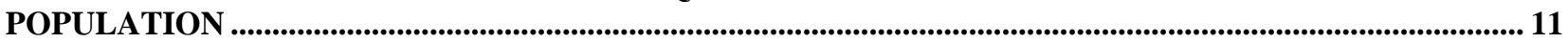

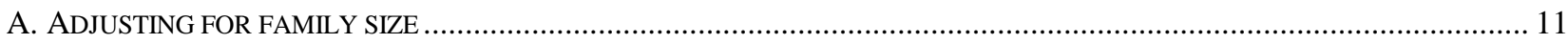

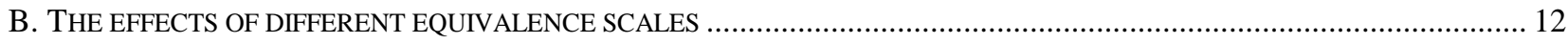

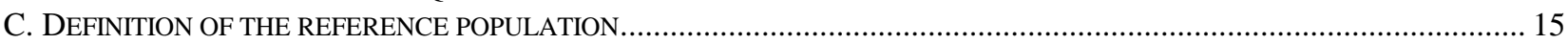

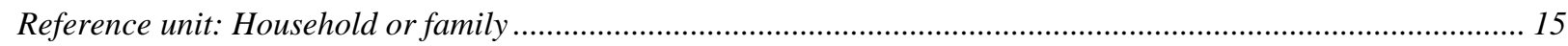

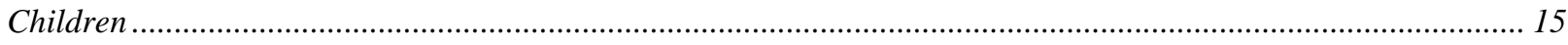

IV. ALTERNATIVE INDICATORS OF LOW INCOME AND POVERTY ……................................................. 16

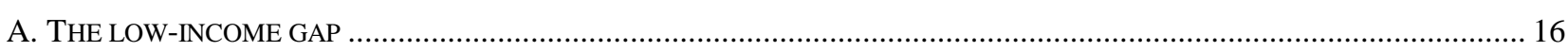

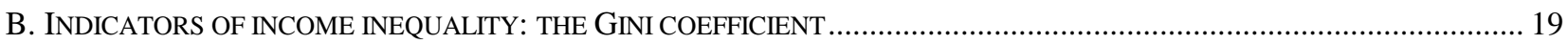

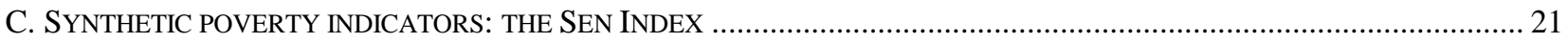

V. APPLICATION OF RELATIVE POVERTY MEASURES TO INCOME DATA FROM 13 OECD

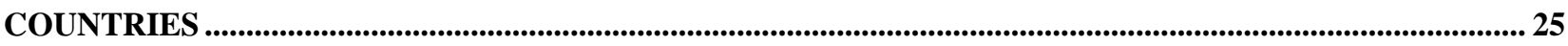

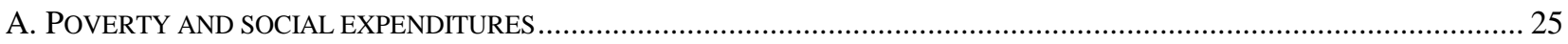

B. THE EFFECTS OF NET TRANSFERS ON RELATIVE INCOMES AMONG NON-ELDERLY FAMILIES .....................................2 27

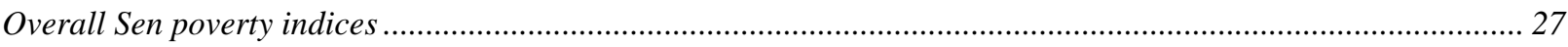

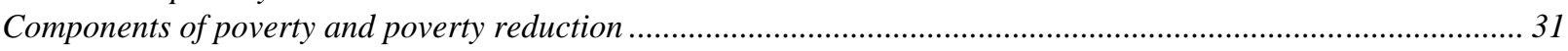

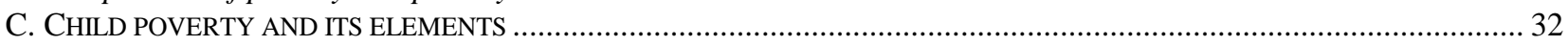

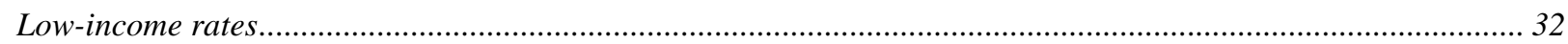

Overall Sen poverty indices and components for children ………................................................................... 32

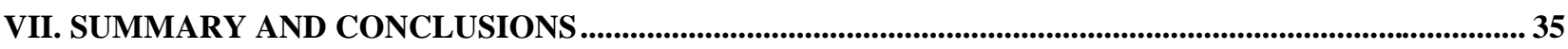

ANNEX 1: THE LUXEMBOURG INCOME STUDY (LIS) ...................................................................................37

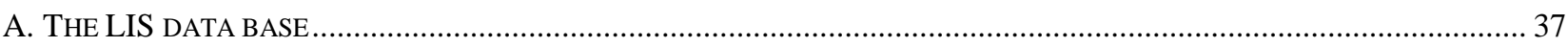

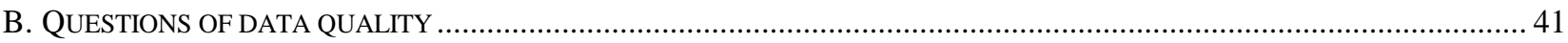

ANNEX 2: THE ANALYTICAL BACKGROUND TO THE SEN INDEX ....................................................... 42

ANNEX 3: STATISTICAL TABLES FOR COMPONENTS OF THE SEN INDEX ............................................. 44

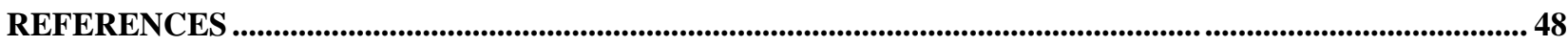




\section{LIST OF TABLES}

TABLE 1. CUMULATIVE PERCENTAGES OF PERSONS IN FAMILIES WITH LOWER INCOMES ......................................... 10

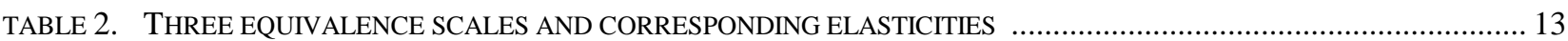

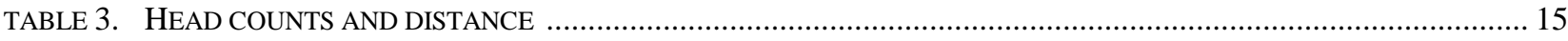

TABLE 4. LOW-INCOME RATES AND AVERAGE LOW-INCOME GAPS FOR NON-ELDERLY FAMILIES ............................... 18

TABLE 5. PROPORTION OF GDP AND SOCIAL EXPENDITURES WHICH WOULD HAVE TO BE SPENT TO

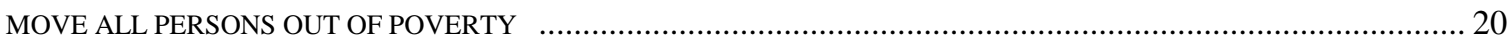

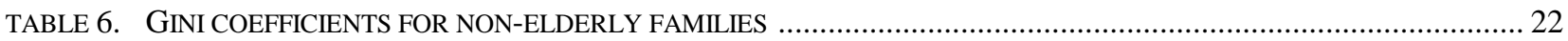

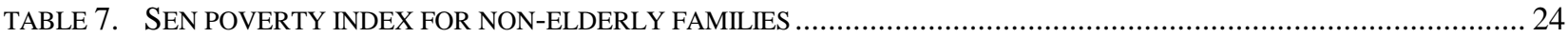

TABLE 8. SEN POVERTY INDEX BEFORE AND AFTER TAXES AND TRANSFERS, FOR THREE DEMOGRAPHIC GROUPS ......... 26

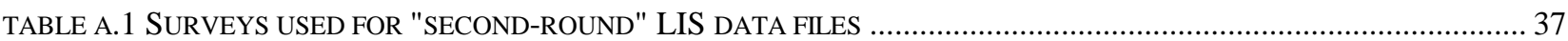

TABLE A.2 POVERTY LINES IN NATIONAL CURRENCIES, FOR THREE DIFFERENT EQUIVALENCE SCALES ........................... 39

TABLE A.3 SEN POVERTY MEASURE AND ITS COMPONENTS BEFORE AND AFTER TAXES AND TRANSFERS,

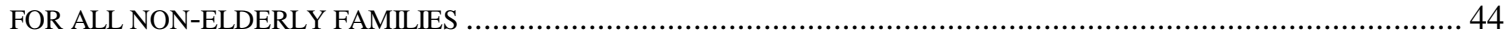

TABLE A.4 SEN POVERTY MEASURE AND ITS COMPONENTS BEFORE AND AFTER TAXES AND TRANSFERS, FOR NON-ELDERLY FAMILIES WITH THREE AND MORE CHILDREN ............................................................... 45

TABLE A.5 SEN POVERTY MEASURE AND ITS COMPONENTS BEFORE AND AFTER TAXES AND TRANSFERS,

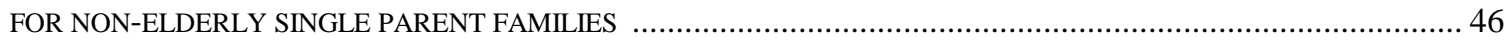

TABLE A.6 SEN POVERTY MEASURE AND ITS COMPONENTS BEFORE AND AFTER TAXES AND TRANSFERS, FOR ALL CHILDREN

\section{LIST OF CHARTS}

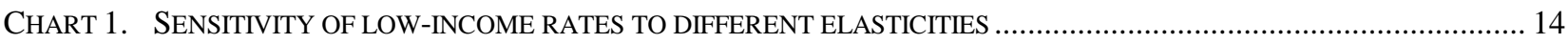

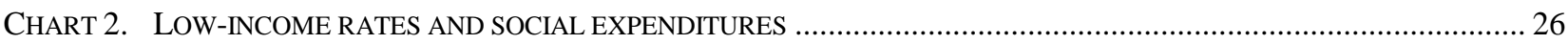

ChART 3. SEN INDEX BEFORE AND AFTER ALLOWANCE FOR NET TRANSFERS, FOR NON-ELDERLY FAMILIES ................ 30

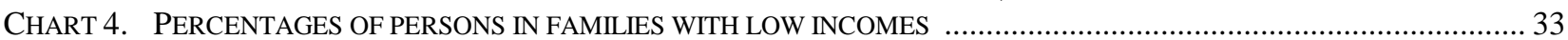

CHART 5. SEN INDEX BEFORE AND AFTER ALLOWANCE FOR NET TRANSFERS, CHILDREN LIVING IN POOR FAMILIES .... 34

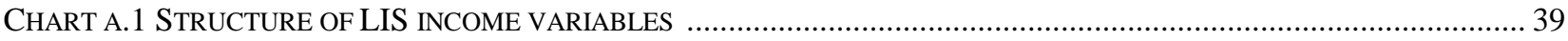




\section{MEASUREMENT OF LOW INCOMES AND POVERTY IN A PERSPECTIVE OF INTERNATIONAL COMPARISONS ${ }^{1}$}

\section{INTRODUCTION}

1. The increase in long-term unemployment in the 1980s in many OECD countries together with a widening in income inequality in some countries has given rise to public concern about poverty. This has inevitably led to a demand for internationally comparable estimates of poverty and on the characteristics of population groups which are at high risk. This paper seeks to make a contribution to this debate by focusing on methodological issues arising from cross-country comparisons of measures of poverty and low income. The aim of this paper is to provide an analytical tool for analysis of poverty levels in a context of international comparison. Different methods for analysing poverty are presented and applied, using micro data sets from the Luxembourg Income Study (see Annex 1).

2. The analysis covers 13 OECD countries which have quite different social regulations and provisions and different approaches towards social policy: Australia, Austria, Belgium, Canada, France, Germany, Ireland, Italy, Luxembourg, the Netherlands, Sweden, the United Kingdom and the United States. One important caveat should be noted: the period of observation refers to a single year in the midto the end-1980s. Hence, the results reported in this paper may not correspond to the current situation with regard to income distribution and levels of poverty in these countries.

3. The analysis will focus on the socio-demographic group of non-elderly families, paying particular attention to families with many children and single parents. A separate section will investigate child poverty. These groups have been shown in many studies (e.g. Mitchell and Bradshaw 1991, Rainwater 1988, Smeeding and Torrey 1988) to be particularly vulnerable to insufficient resources. Analyses comparing income micro-data for a year in the early 1980s with a year in the mid- to end-1980s across countries (e.g. Smeeding and Rainwater 1991) show some shift in the incidence of poverty from the elderly to the non-elderly in many countries.

1. This paper owes very much to John Martin and Peter Scherer for their suggestions, detailed comments and substantive discussions. Also, Lee Rainwater, Robert Holzmann, Anastasia Fetsi, István Tóth and Uwe Warner provided very useful comments and suggestions on earlier drafts of this paper. 


\section{DIFFERENT APPROACHES TO DEFINING LOW INCOME AND POVERTY}

4. The various approaches used in the literature to measure poverty all have in common the establishment of a cut-off-line below which persons or families are considered to have an inadequate income (low income cut-off-line) or to be poor (poverty line). Sometimes, poverty is defined in terms of household expenditure rather than income (e.g. EUROSTAT 1990). This paper uses low (disposable) income as an indicator for poverty because it focuses on the capacities of individuals and families to participate in the mainstream of their society rather than on their actual spending behaviour.

5. In the past decade, the debate on how to measure poverty and low incomes has focused on three different concepts:

i) The absolute approach (or, as Hagenaars/de Vos (1987) put it, "having less than an objectively defined absolute minimum")

ii) The relative approach (or, "having less than others")

iii) The subjective approach (or, "feeling you do not have enough to get along")

The rest of this chapter discusses these concepts in detail.

\section{A. The absolute approach}

6. This concept is the basis for most 'official' definitions of low income. It defines an absolute subsistence minimum in terms of basic needs (for food, clothing, housing etc.). The aggregate cost of these goods and services then constitutes the low-income line. One such example is the current U.S. Social Security Administration Poverty Index, developed by Orshansky $(1965,1969)$. The derived absolute poverty line is adjusted by the Consumer Price Index on an annual basis.

7. Other countries implicitly define 'official' low-income lines, based on the absolute approach implicit in the sense that they calculate minimum income levels for administrative purposes (levels below which families become eligible for income support programmes). Examples are the social assistance (Bundessozialhilfe) in Germany which is based on a detailed basket of goods deemed necessary, or the social aid programme in Austria.

8. The common use of absolute low-income and poverty lines in policy debate can be explained by the fact that they permit analysts to quantify easily the effects of social programmes (in particular income maintenance programmes targeted to the poor) over a short or medium-term period. Difficulties arise, however, when the base of the absolute measure (e.g. the basket of needs) has to be changed. In addition, cross-country comparisons are extremely difficult because the absolute measures are always defined on a national level. 
9. The most critical feature of the absolute approach is undoubtedly the arbitrary nature of the choice as to what constitute basic needs. If this holds true at a national level, the disadvantages of the absolute approach are even more striking when comparing across countries. Some authors have tried to set one absolute low-income level (e.g. the U.S. poverty line), converting it to other countries' income levels with the help of Purchasing Power Parities (e.g. Smeeding/Torrey 1988; Short/Garner 1989). But this approach is not appropriate for comparative social policy analysis. Even under the assumption that basic needs are the same across countries, it is preferable to use measures and indicators which give the same weight and importance to each country's standards. In addition, Purchasing Power Parities are not designed for poverty comparisons. Applying them to the poor assumes that they have the same consumption basket as the total population which is likely to be untrue.

10. Another problem with the use of absolute measures is that - once the absolute level is set - the numbers falling below this measure correlate closely with recessions and economic booms. This can be illustrated by the evolution of the U.S. poverty line: the number of persons in poverty has fluctuated over the past two decades in line with the business cycle, whereas alternative U.S. poverty measures show a steady decline (for elderly) or increase (for children). Theoretically, economic growth might eliminate low income, if the latter is defined in absolute terms (and adjusted only for price changes), without any special poverty programme and without changing the income distribution - provided the entire population shares in growth (OECD 1976).

\section{B. The relative approach}

11. The relative approach tries to overcome these difficulties by judging incomes as low with respect to the incomes, or the well-being level, of the population as a whole. It thus takes into account the different levels of well-being within a society and how it changes over time. Relative measures also allow one to compare income situations across countries, because they are independent of a specific country's definition of basic needs.

12. The simplest relative income measure is to set a low-income line at a certain bottom percentile of the income distribution, defining for instance the low-income population as households in the bottom quintile of equivalent income. Whilst this measure provides cross-country comparable results for the household characteristics of the lowest 20 percent of the income distribution, it rules out cross-country comparisons of poverty rates, since the number of low-income families will always be equal to one fifth to the total population.

13. Another more complex variant of this approach defines low income as a fraction of average or median income (the so-called economic distance approach). In this case, the proportion of low-income families varies across time (and countries). There is no specific argument to opt for one percentage level rather than another (say, $60 \%$ of the median rather than 50\%). But the presentation of various percentage levels may serve as benchmarks for policy making.

14. Traditionally, international comparative studies have made use of relative methods to determine low-income lines, e.g. EUROSTAT (1990), OECD (1982) and ILO (1978). Relative poverty measures, which define poverty in the context of a given society, undoubtedly provide valuable estimates for the comparison of the number and composition of families with low incomes across countries. 


\section{The subjective approach}

15. Both absolute and relative measures may be regarded as objective indicators of low income. On the contrary, subjective measures of low income are based on public opinion on income levels considered to be 'just sufficient', derived from household surveys. Such measures thus avoid the problem of the arbitrary choice of basic needs made by experts.

16. Several subjective methods have been developed to determine low-income levels: the SPL-method ("subjective poverty line"; Goedhart; Van Praag et al.), the CSP-method (Centre of Social Policy/University of Antwerp; Deleeck), the LPL-method ("Leyden poverty line"; Van Praag et al.) and the social consensus method (Piachaud; Walker; Mack and Lansley).

17. Initial research in Europe based on subjective measures suggests that the derived low-income levels lie, in general, above those calculated with traditional absolute or relative measures (Deleeck/van der Bosch 1989). A study which compares subjective poverty lines derived from the U.S. Consumer Expenditure Interview with a survey conceived by the Dutch Centre for Research in Public Economics concludes that "subjective poverty lines are considerably above the official poverty lines, but more so in the U.S. than in the Netherlands" (De Vos/Garner 1989: 14).

18. At first sight, the subjective approach appears quite attractive because the low-income level is defined by the concerned population itself. However, very few regular (income or budget) surveys incorporate a minimum income question, and the precise formulations of the questions differ considerably. Thus, subjective standards may vary across time and, moreover, across countries. Therefore, while subjective approaches may provide useful methods to measure the low-income population in a particular country at a particular time, they are not for the time being suitable for comparative research.

\section{The effects of choosing a particular approach}

19. The adoption of a particular approach to define low income is not an academic question; the absolute number and also the structure of the population in poverty may vary dramatically according to the method chosen. Hagenaars/de Vos (1987) apply eight definitions of a poverty line to a 1983 household survey in the Netherlands (four definitions based on an absolute approach, three on a subjective and one on a relative measure): the derived overall poverty rates ranged from 5.7 to 33.5 percent of the total population.

20. If the purpose of the analysis is cross-country comparison rather than comparison over time, a relative definition of low income is the most useful approach to assess poverty. Low income will then be defined as a certain fraction of the disposable income. As a reference point, the median income level is preferred to the mean as it reflects better the most widely shared life style (i.e. the resources needed for it). As a reference distance, 50 percent of the median income is proposed (this definition was first suggested by Fuchs 1967). In order to test the sensitivity of results, three different distance levels will be presented:

$40 \%$ (close to the levels of the U.S. poverty line and a U.K. poverty line derived from Supplementary Benefit)

$50 \%$ (a level often used for international comparisons, e.g. EUROSTAT, LIS)

- $\quad 60 \%$ (close to the level of the Swedish existence minimum income). 
21. It should be stressed that a low-income line does not represent a break- even point below which a person (or family) suddenly becomes poor. Instead, low-income lines serve to define several classes of low income. Table 1 presents such low-income classes using data from the Luxembourg Income Study.

Table 1: Cumulative percentages of persons in families with low incomes

\begin{tabular}{lrrrrrr}
\hline & & \multicolumn{5}{c}{ Percent of median income } \\
& 20 & 30 & 40 & 50 & 60 & 70 \\
\hline Australia 85/86 & 1.9 & 3.4 & 5.9 & 12.9 & 21.0 & 29.1 \\
Austria 87 & 0.2 & 0.8 & 2.6 & 6.7 & 12.2 & 19.6 \\
Belgium 85 & 0.5 & 1.0 & 1.9 & 4.4 & 10.7 & 19.6 \\
Canada 87 & 1.5 & 2.9 & 7.5 & 12.1 & 18.1 & 26.3 \\
France 84 & 1.0 & 2.2 & 3.9 & 7.1 & 13.2 & 23.3 \\
Germany 84/85 & 0.4 & 1.0 & 2.7 & 6.4 & 12.4 & 20.9 \\
Ireland 87 & 1.9 & 3.0 & 4.4 & 12.3 & 20.1 & 27.8 \\
Italy 86 & 0.7 & 2.7 & 5.6 & 11.0 & 18.0 & 27.6 \\
Luxembourg 85 & 0.2 & 0.7 & 1.7 & 5.1 & 10.8 & 21.1 \\
Netherlands 87 & 0.7 & 0.9 & 1.9 & 3.9 & 8.3 & 16.3 \\
Sweden 87 & 1.4 & 2.6 & 4.2 & 6.8 & 11.8 & 19.4 \\
United Kingdom 86 & 1.5 & 2.3 & 3.9 & 8.7 & 17.3 & 26.5 \\
United States 86 & 2.9 & 7.3 & 12.8 & 18.4 & 24.1 & 30.3 \\
Average (unweighted) & 1.1 & 2.4 & 4.5 & 8.9 & 15.2 & 23.7 \\
\hline
\end{tabular}

Source: LIS micro data base

Note: income concept used is disposable income adjusted for family size, using an equivalence scale with an elasticity of 0.55 (see chapter III).

22. Three groups of countries can be distinguished in Table 1:

i) Australia, Canada and the United States (especially at the top end of the scale) all have low-income rates well above the average in all income segments;

ii) the continental European countries -- Austria, Belgium, Germany, Luxembourg and the Netherlands -- are at the bottom in all of the segments. Within this grouping, Austria and Luxembourg have the lowest values for the very low income segments (below 20 and $30 \%$ ); this means that the poor population in these countries is concentrated towards higher cut-off lines (50 and 60\%). In Belgium and the Netherlands, the poor population seems to be more equally distributed within the segments;

iii) the remaining European countries -- France, Ireland, Italy, Sweden and the United Kingdom -- have low-income rates close to the average, but there are different patterns according to the segment. In the 50 to $70 \%$ range, for instance, France and Sweden have low-income rates 
significantly below the average, whereas Italy and Ireland have rates close to those of the first country group.

23. Further analysis of Table $\mathbf{1}$ reveals some country-specific patterns: some countries (Italy) have below-average rates in the lowest income segment (below 20\%) but above-average rates when moving to higher low-income segments. Other countries (Sweden) show the opposite picture. Both Ireland and the United Kingdom have above-average rates for the very poor population, average or below-average rates for the segments often defined as the 'core' of the poor (below 40 and 50\%), and above-average rates for the population 'near poverty' (60 and $70 \%$ segment).

\section{HOW TO ADJUST FAMILY INCOME: EQUIVALENCE SCALES AND THE REFERENCE POPULATION}

\section{A. Adjusting for family size}

24. Once the low-income line (or lines) have been defined, the reference income measure (disposable family income) has to be adjusted for family size. One can assume that, due to economies of scale, the needs of a family for resources grow with each additional member, but not in a proportional way. With the help of equivalence scales, each family type in the population is assigned a value in proportion to its needs ${ }^{2}$.

25. Equivalence scales can be represented by one single parameter, the equivalence elasticity, i.e. the power by which needs increase as family size increases:

$$
\begin{aligned}
& N=S^{e}, \text { or } \\
& e=\frac{\ln (N)}{\ln (S)}, 0 \leq e \leq 1 \\
& \text { where } e \text { : equivalence elasticity } \\
& N \text { : economic need (proxied by disposable income / economic well-being) } \\
& S: \quad \text { family size }
\end{aligned}
$$

The equivalence elasticity, $e$, thus can range from 0 (when unadjusted family disposable income is taken as the income measure) to 1 (when per capita family income is used). The smaller the value for $e$, the higher are the assumed economies of scale.

2. Some comparative studies also adjust the incomes for the age structure of a family. Rainwater (1988) shows for 9 OECD countries (around 1980), that adjusting for the age of the family head decreases the overall low-income rate for all countries by 10 to 20 percent. On the other hand, the rankings between countries were generally not affected. This paper uses family size as the sole determinant for adjustment. 
26. Buhmann et al. (1988) reviewed a large inventory of some 30 equivalence scales. They can be split into two broad groups, one being based on experts' judgement (i and ii) and the other on surveys (iii and iv):

i) Expert statistical judgement: scales developed primarily for statistical and comparative purposes, e.g. the U.S. Bureau of Labor Statistics family budgets, EUROSTAT (1990), or the OECD List of Social Indicators (OECD 1982). Their equivalence elasticities lie around 0.74 .

ii) Expert programme judgement: scales implicitly used for calculating benefits of social programmes, such as the Swiss social assistance, the Swedish base amount, the U.K. Supplementary benefits, or the U.S. poverty definition. These equivalence elasticities lie around 0.55 .

iii) Scales based on analysis of household consumption expenditure patterns as derived from household surveys, e.g. the Statistics Canada method, van der Gaag/Smolensky (1982) for the United States, or, more recently, Glaude/ Moutardier (1989) for France. The derived equivalence elasticities lie around 0.4 to 0.5 .

iv) An alternative survey-based method measures utility directly from public opinion polls (see in particular Van der Gaag et al. 1982 and Rainwater 1990). These methods generally yield the lowest values for $e$ (around 0.25).

\section{B. The effects of different equivalence scales}

27. In order to assess how sensitive low-income rates are to alternative equivalence scales for family size, we used three typical equivalence scales as well as family income and per-capita income (see Table 2).

28. Equivalence scales derived by self-assessment from household surveys (EQ1) typically underestimate the costs of additional family members. 'Statistical' equivalence scales (EQ3) represent one extreme in the possible choice. 'Policy-based' scales (EQ2) represent values which are inherent in many social programmes of OECD member countries, and also come quite close to equivalence values found in several surveys on household consumption expenditures. 
Table 2: Three equivalence scales and corresponding elasticities

\begin{tabular}{cllllc}
\hline $\begin{array}{c}\text { Family } \\
\text { size }\end{array}$ & EQ1 $^{1}$ & EQ2 $^{2}$ & EQ3 $^{3}{ }^{4}{ }^{4}$ & $\begin{array}{c}\text { family } \\
\text { income }\end{array}$ & $\begin{array}{c}\text { per- } \\
\text { capita } \\
\text { income }\end{array}$ \\
\hline 1 & 1 & 1 & 1 & 1 & 1 \\
2 & 1.26 & 1.50 & 1.7 & 1 & 2 \\
3 & 1.44 & 1.88 & 2.2 & 1 & 3 \\
4 & 1.58 & 2.18 & 2.7 & 1 & 4 \\
5 & 1.70 & 2.40 & 3.2 & 1 & 5 \\
6 & 1.81 & 2.63 & 3.7 & 1 & 6 \\
7 & 1.90 & 2.85 & 4.2 & 1 & 7 \\
elasticity & 0.33 & 0.55 & 0.73 & 0 & 1 \\
\hline
\end{tabular}

Notes:

${ }^{1}$ EQ1 corresponds to equivalence scales, typically derived by self-assessment through surveys.

2 EQ2 corresponds to most equivalence scales inherent in many national social programmes; it was also used as poverty measure in OECD (1976).

3 EQ3 corresponds to the equivalence scale suggested in OECD Social Indicators (1982).

4 The figures shown assume that the third and higher members of the family are children.

29. In selecting a particular equivalence scale, it is important to be aware of the potential effects on the size of the low-income population, its composition, and the relative positions of countries in international comparisons. The research of Buhmann et al. (1988) suggests that, in general, adjusted low-income rates are lower at higher elasticities. It should be noted, however, that this is not a linear function and that one can get 'u-shaped' results when including the two extreme values for e, 0 and 1 .

30. Chart 1 shows that this holds true for all the 13 OECD countries under review. This means that one cannot simply calculate low-income rates for two extreme equivalence scales and assume that intermediate scales would lead to intermediate low-income estimates. In a few countries (Australia, Austria, Sweden), the low-income rate - defined here at the 50\% level - is reduced by one third or more when shifting from EQ1 to EQ3. In the other countries the adoption of different equivalent scales does not have such a significant impact on overall low-income levels. Also, the ranking of countries is, in general, not affected by the use of different equivalent scales (with the notable exception of the three countries already mentioned).

31. As for the composition of the low-income population, almost by definition, the larger the elasticity, the greater the share of large families (thus children) among the low-income population and the smaller the share of single persons (thus elderly) and older married couples. Buhmann et al. (1988) show that percentage shares in low income of specific demographic groups, such as couples with two or more children, may double (or triple for some countries) when shifting from a low e-value (0.25) to a high one (0.72). However, at the same time the ranking of countries in cross-country comparison does not change dramatically, neither for low-income rates, nor for population shares (due to similar overall family structures in industrialised countries). 
Chart 1: Sensitivity of low-income rates to different equivalence elasticities
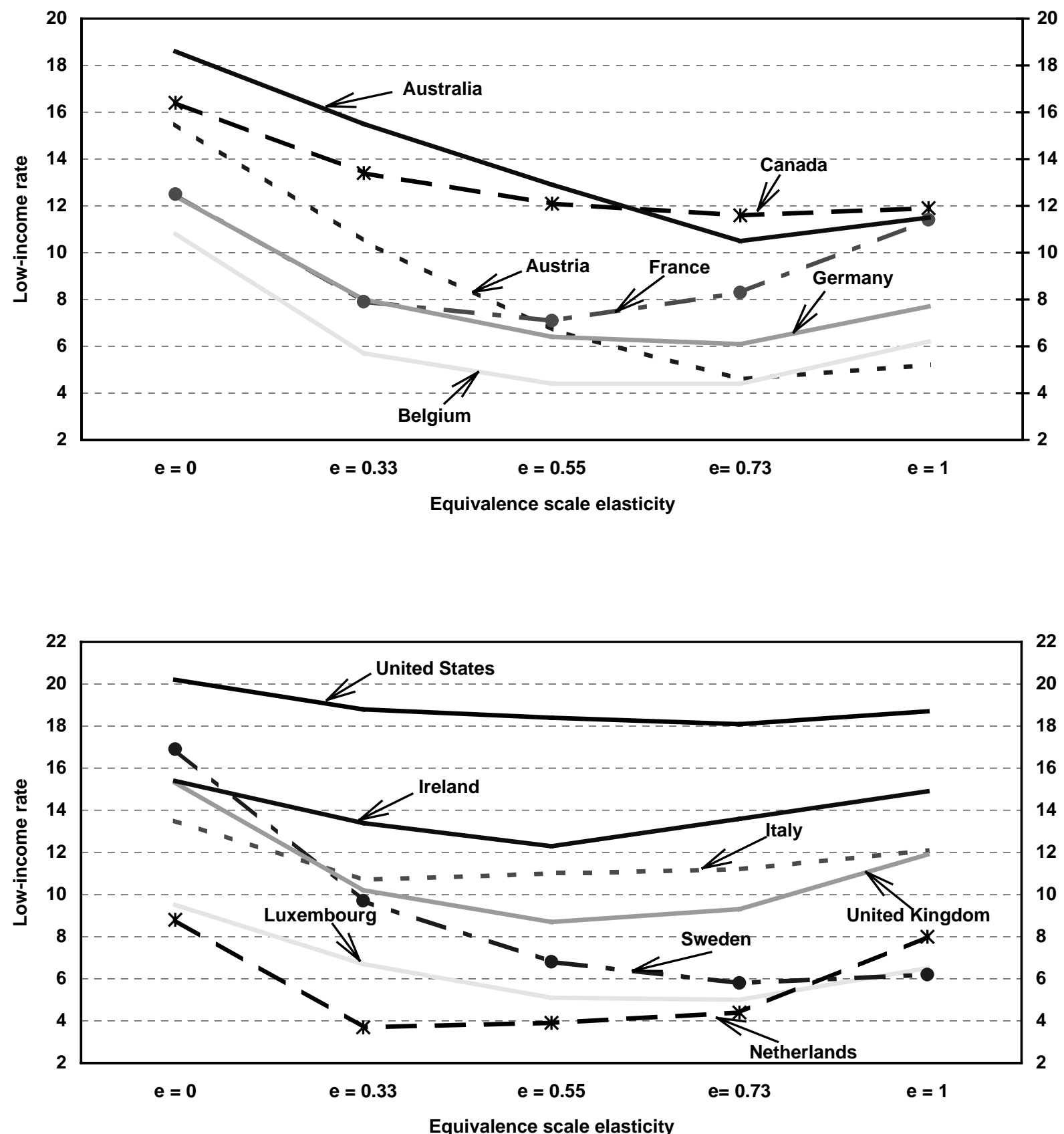

Source: LIS micro data base

Note: Low-income rate defined as percentage of persons in families with disposable incomes below $50 \%$ of median adjusted disposable income. 
32. The second part of this paper (chapters IV, V and VI) analyses the relative income positions among non-elderly families. As the focus will be on public policy actions to alleviate poverty, EQ2 -- the 'policy-based' scale -- will be used to adjust family incomes.

\section{Definition of the reference population}

\section{Reference unit: Household or family}

33. A further methodological question to be answered refers to the definition of the reference unit of observation: the household or the family? The argument for choosing the household as the basic reference unit is the observation that economies of scale and shared resources exist in a same household notwithstanding marriage or blood relationship among its members. On the other hand, the interest of the analysis in chapters IV and V of the paper lies in families with children (including single-parent families). Therefore, for this part of the study, non-elderly families (i.e. families with a head aged less than 60) have been chosen as the reference population. Unfortunately, data for Italy and the Netherlands are only available on a household basis.

34. In general, the computed poverty estimates in this paper were not very sensitive to the choice of the weight (person or household/family weight), i.e. whether the population in poverty is defined as the number of persons living in poor families or as the number of poor families. There is, however, one exception: a particular unit definition for Sweden based on tax units is likely to result in overestimates of poverty for this country when using household (family) weights (see Annex 1).

\section{Children}

35. Since part of the analysis will focus on children (as members of their families or as the reference population), it is important to be clear on the definition of children and their status inside the family unit. First, there is the question of the reference age. There are several possibilities for an age cut-off:

i) Compulsory school age (14 to 16 years): this would define a quite coherent population of young people who can safely be considered as entirely dependent on their families' resources.

ii) Cut-off age of 18: this definition, used in the Luxembourg Income Study, would constitute a group of persons of the same age across countries.

iii) Age with regard to administrative regulations, such as child allowance, scholarship.

36. Even if the reference age is defined in one of the above ways, there remain considerable difficulties for the analysis. Should persons over the cut-off age but in full-time education be considered as adults? How should persons who are both parents and children in terms of an age cut-off be classified? 
37. Unfortunately, the surveys in the LIS micro data-base do not allow alternative break-downs of categories for children. Therefore, for the analysis in chapters IV and V, children will be defined according to the classification of the LIS data sets, i.e. as unmarried persons under the age of 18 living in the family.

38. A final question relates to the observation unit: should we speak of children's poverty (or children with low income) or of low-income families with children? In many studies, low-income rates are calculated by defining the number of poor children with respect to the total population of children. In this study, the quantitative analysis will focus primarily on the well-being status of families with children. A standard head-count ratio, for this type of analysis, will be: the percentage of low-income families with children. In addition, for specific investigations of 'child poverty' and the effects of net transfers on the population of children (chapter V), the following head-count ratio will be used: the percentage of children living in low-income families.

\section{ALTERNATIVE INDICATORS OF LOW INCOME AND POVERTY}

\section{A. The low-income gap}

39. Up to now, the discussion of measures of poverty has been restricted to comparisons of head-count ratios, i.e. the number of persons or families with low incomes as a proportion of the total population. This simple indicator, the so-called "low-income rate", provides useful information on the incidence of low-income situations but does not capture the intensity of such situations, i.e. how far the low-income population falls below a given cut-off line. To illustrate this limitation, consider the case of countries I and II in table 3, which each have the same population (1 000000$)$ and low-income line z. Although Country I has a higher low-income rate than Country II, the amount necessary to bring all families above the low-income threshold would be one and a half times higher in the latter. Policy considerations might therefore differ when there is a lack of information on the intensity of low incomes.

Table 3: Head counts and distance

\begin{tabular}{lccccc}
\hline & $\begin{array}{c}\text { number of low- } \\
\text { income families }\end{array}$ & $\begin{array}{c}\text { low-income } \\
\text { rate }\end{array}$ & $\begin{array}{c}\text { average income } \\
\text { of these families }\end{array}$ & z & $\begin{array}{c}\text { necessary } \\
\text { amount }\end{array}$ \\
\cline { 2 - 6 } Country I & 12000 & $12 \%$ & 10 & 15 & 60000 \\
Country II & 10000 & $10 \%$ & 6 & 15 & 90000 \\
\hline
\end{tabular}

3. The analysis in chapters IV and V neglects differences in intra-family transfers and distributions, i.e. it is assumed that children in all families share equally their family resources. For a discussion of intra-family inequality and possible effects on poverty and distribution estimates, see for example Haddad and Kanbur 1990, and Qvortrup 1990. 
40. A common indicator of this intensity is the average low-income gap (ALG), which is defined as the difference between the average income of the low-income population and the low-income line, as a percentage of that line. The head-count ratio (LIR) and average low-income gap (ALG) are defined as follows:

$$
\begin{aligned}
& \text { LIR }=\frac{q}{n} \\
& \begin{aligned}
\mathrm{ALG}= & \frac{z-\bar{y}_{q}}{z} \\
= & \frac{1}{q} \sum_{i=1}^{q} \frac{z-y_{i}}{z}
\end{aligned} \\
& \text { where } \quad \begin{aligned}
q & =\text { number of persons having incomes below } \mathrm{z}, \\
& =\text { total population, } \\
& z=\text { low-income threshold, } \\
& y_{i}=\text { income of the ith individual of the low-income population, } \\
& y_{q}=\text { average income of the low-income population. }
\end{aligned}
\end{aligned}
$$

41. Table 4 shows low-income rates and average low-income gaps using three different low-income levels. The data refer to non-elderly families (families with a head aged less than 60). The incidence of poverty (measured by the low-income rate at its 50 percent segment) is lowest in Luxembourg and the Netherlands, and highest in the United States, Australia and Ireland. As to the intensity of poverty, in general, average low-income gaps are well below the average for Austria, Luxembourg and Germany, and above average for $\mathrm{Sweden}^{4}$ and the United States.

42. It is interesting to note that for almost half of the countries the low-income gaps are significantly higher for those families which are situated below the lowest of the three income levels (40\%): Belgium, France, Luxembourg, the Netherlands and the United Kingdom. In these countries, the share of non-elderly families which have very low incomes is, on average, also far below the cut-off line. In the other group (Australia, Austria, Canada, Germany, Italy, Sweden, United States), the average income shortfall is about the same in each of the three low-income levels.

43. Comparing low-income rates between countries without paying due attention to the income levels of the low-income population may be insufficient for policy considerations. Table 4 reveals that some countries which have similar levels of low-income incidence experience quite different patterns as to the intensity of low incomes of the population concerned. This is for example the case for Ireland and Italy (at the $40 \%$ level), France and Germany (at the 50\% level), or Canada and the United Kingdom (at the $60 \%$ level).

4. As noted in the text, due to a different unit definition, the results for Sweden are not fully comparable with those of the other countries (see Chapter III, section D, and Annex 1). 
Table 4: Low-income rates and average low-income gaps for non-elderly families

\begin{tabular}{|c|c|c|c|}
\hline & & Low-income rate (LIR) & Low-income gap (ALG) \\
\hline Australia $85 / 86$ & $\begin{array}{l}<40 \% \text { of median } \\
<50 \% \text { of median } \\
<60 \% \text { of median }\end{array}$ & $\begin{array}{r}8.9 \\
15.7 \\
21.3 \\
\end{array}$ & $\begin{array}{l}33.5 \\
30.7 \\
33.4 \\
\end{array}$ \\
\hline Austria 87 & $\begin{array}{l}<40 \% \text { of median } \\
<50 \% \text { of median } \\
<60 \% \text { of median }\end{array}$ & $\begin{array}{r}3.0 \\
6.2 \\
11.2\end{array}$ & $\begin{array}{l}23.4 \\
24.0 \\
24.5\end{array}$ \\
\hline Belgium 85 & $\begin{array}{l}<40 \% \text { of median } \\
<50 \% \text { of median } \\
<60 \% \text { of median }\end{array}$ & $\begin{array}{r}2.3 \\
5.4 \\
11.6\end{array}$ & $\begin{array}{l}34.6 \\
25.0 \\
21.3\end{array}$ \\
\hline Canada 87 & $\begin{array}{l}<40 \% \text { of median } \\
<50 \% \text { of median } \\
<60 \% \text { of median }\end{array}$ & $\begin{array}{l}10.5 \\
15.4 \\
21.1\end{array}$ & $\begin{array}{l}30.3 \\
33.2 \\
34.4\end{array}$ \\
\hline France 84 & $\begin{array}{l}<40 \% \text { of median } \\
<50 \% \text { of median } \\
<60 \% \text { of median }\end{array}$ & $\begin{array}{r}5.2 \\
8.9 \\
15.0\end{array}$ & $\begin{array}{l}37.9 \\
33.3 \\
29.6\end{array}$ \\
\hline Germany $84 / 85$ & $\begin{array}{l}<40 \% \text { of median } \\
<50 \% \text { of median } \\
<60 \% \text { of median }\end{array}$ & $\begin{array}{r}3.8 \\
8.5 \\
14.5 \\
\end{array}$ & $\begin{array}{l}23.4 \\
23.2 \\
24.2\end{array}$ \\
\hline Ireland 87 & $\begin{array}{l}<40 \% \text { of median } \\
<50 \% \text { of median } \\
<60 \% \text { of median }\end{array}$ & $\begin{array}{r}5.5 \\
15.7 \\
23.4 \\
\end{array}$ & $\begin{array}{l}42.2 \\
24.9 \\
27.4\end{array}$ \\
\hline Italy 86 & $\begin{array}{l}<40 \% \text { of median } \\
<50 \% \text { of median } \\
<60 \% \text { of median }\end{array}$ & $\begin{array}{r}5.6 \\
10.1 \\
17.3\end{array}$ & $\begin{array}{l}27.5 \\
27.3 \\
26.3\end{array}$ \\
\hline Luxembourg 85 & $\begin{array}{l}<40 \% \text { of median } \\
<50 \% \text { of median } \\
<60 \% \text { of median }\end{array}$ & $\begin{array}{r}1.7 \\
4.5 \\
10.6\end{array}$ & $\begin{array}{l}32.9 \\
22.4 \\
19.0\end{array}$ \\
\hline Netherlands 87 & $\begin{array}{l}<40 \% \text { of median } \\
<50 \% \text { of median } \\
<60 \% \text { of median }\end{array}$ & $\begin{array}{r}2.4 \\
4.7 \\
11.3 \\
\end{array}$ & $\begin{array}{l}33.2 \\
28.8 \\
20.9 \\
\end{array}$ \\
\hline Sweden 87 & $\begin{array}{l}<40 \% \text { of median } \\
<50 \% \text { of median } \\
<60 \% \text { of median }\end{array}$ & $\begin{array}{r}6.9 \\
10.6 \\
16.1\end{array}$ & $\begin{array}{l}40.4 \\
41.0 \\
40.0\end{array}$ \\
\hline United Kingdom 86 & $\begin{array}{l}<40 \% \text { of median } \\
<50 \% \text { of median } \\
<60 \% \text { of median }\end{array}$ & $\begin{array}{r}5.6 \\
12.4 \\
20.6\end{array}$ & $\begin{array}{l}38.3 \\
27.6 \\
26.9\end{array}$ \\
\hline United States 86 & $\begin{array}{l}<40 \% \text { of median } \\
<50 \% \text { of median } \\
<60 \% \text { of median }\end{array}$ & $\begin{array}{l}13.9 \\
18.7 \\
24.4\end{array}$ & $\begin{array}{l}37.0 \\
39.4 \\
39.8 \\
\end{array}$ \\
\hline Average (unweighted) & $\begin{array}{l}<40 \% \text { of median } \\
<50 \% \text { of median } \\
<60 \% \text { of median }\end{array}$ & $\begin{array}{r}5.8 \\
10.5 \\
16.8\end{array}$ & $\begin{array}{l}33.4 \\
29.3 \\
28.3\end{array}$ \\
\hline
\end{tabular}

Source: $\quad$ LIS micro data base.

Notes: $\quad$ Non-elderly families: Families headed by a person aged less than 60 . Low-income rate: percent of families of each type whose adjusted disposable income is below a certain percentage of the median adjusted income. Low-income gap: difference between average low income and the low income line, as a percentage of that line. Income adjusted for family size (equivalence elasticity $=0.55$ ). 
44. When the average low-income gap (ALG) is multiplied by the absolute number of people with low incomes and expressed as a percentage of GDP or social expenditures rather than the cut-off line (z), it provides an illustrative measure of the amount of social transfers which would have to be spent in order to bring the entire population above the low-income threshold. Table 5 provides some illustrative calculations of how much additional spending might be involved in this. It shows that the percentage of GDP necessary to eliminate poverty, defined as below 50 percent of the median income, would in no country except the United States be bigger than one percent. When poverty is defined as below 60 percent of the median income, low-poverty countries would have to spend around 0.6 to 0.8 percent of their GDP to pull persons out of poverty. In high-poverty countries, this percentage would be between 1.5 and 2.5 percent, in the remaining countries around one percent.

\section{B. Indicators of income inequality: the Gini coefficient}

45. However, a further aspect of low income must also be taken into account, namely the fact that some low-income families are poorer or richer than others. The low-income rate says nothing about the distribution of incomes among low-income families. This aspect of poverty is also ignored by the low-income gap as it measures the distance below the average low income and the low-income line and is therefore insensitive to redistribution among the low-income population.

46. The Lorenz curve is a familiar construction to illustrate graphically the concentration of incomes. It plots cumulative proportions of the population, from the poorest upwards, against the cumulative shares of incomes that they receive. If all incomes were identical, this would trace a diagonal $45^{\circ}$-line ("line of perfect equality"). In the other extreme case -- if the richest unit would receive all the income -- the Lorenz curve would lie along the horizontal axis, and then along the vertical axis at the 100 percent income share ("line of perfect inequality"). In reality, Lorenz curves lie between these two extremes ${ }^{5}$.

47. A derived summary statistic used to characterise the distribution of incomes is the Gini coefficient which is defined as the area between the Lorenz curve and the $45^{\circ}$ line as a ratio of the whole triangle. The Gini coefficient $(G)$ lies between 0 -- when all incomes are distributed equally, and 1 -- when there is perfect inequality. The literature contains various methods to express the Gini coefficient ${ }^{6}$; a common formula is:

$$
G=\frac{2}{n^{2} \bar{y}} \sum_{i=1}^{n} i\left(y_{i}-\bar{y}\right)
$$

where the $y_{i}$ are ranked in ascending order by their subscripts.

5. There are three possibilities when comparing Lorenz curves for different income distributions: dominance, equivalence and non-comparability (intersecting Lorenz curves). The latter case has been widely discussed in the literature (e.g. Atkinson 1970; Shorrocks 1983; Buhmann et al. 1988; Bishop et al. 1991).

6. For an extensive discussion of measures of income inequality and the Gini coefficient, see Morris/Preston 1986, OECD 1990b: 220 ff, and OECD 1994 (forthcoming). 
Table 5: Proportion of GDP and social expenditures which would have to be spent to pull all persons out of poverty

\begin{tabular}{|c|c|c|c|}
\hline & & percent of GDP & $\begin{array}{c}\text { percent of social } \\
\text { expenditures }\end{array}$ \\
\hline \multirow[t]{3}{*}{ Australia $85 / 86$} & $<40 \%$ of median & 0.4 & 2.1 \\
\hline & $<50 \%$ of median & 0.8 & 4.0 \\
\hline & $<60 \%$ of median & 1.4 & 7.2 \\
\hline \multirow[t]{3}{*}{ Austria 87} & $<40 \%$ of median & 0.1 & 0.2 \\
\hline & $<50 \%$ of median & 0.3 & 0.8 \\
\hline & $<60 \%$ of median & 0.6 & 2.0 \\
\hline \multirow[t]{3}{*}{ Belgium 85} & $<40 \%$ of median & 0.1 & 0.3 \\
\hline & $<50 \%$ of median & 0.3 & 0.8 \\
\hline & $<60 \%$ of median & 0.7 & 2.0 \\
\hline \multirow[t]{3}{*}{ Canada 87} & $<40 \%$ of median & 0.4 & 1.7 \\
\hline & $<50 \%$ of median & 0.9 & 3.7 \\
\hline & $<60 \%$ of median & 1.6 & 6.7 \\
\hline \multirow[t]{3}{*}{ France 84} & $<40 \%$ of median & 0.3 & 0.8 \\
\hline & $<50 \%$ of median & 0.6 & 1.9 \\
\hline & $<60 \%$ of median & 1.3 & 3.9 \\
\hline \multirow[t]{3}{*}{ Germany 84/85 } & $<40 \%$ of median & 0.1 & 0.4 \\
\hline & $<50 \%$ of median & 0.3 & 1.1 \\
\hline & $<60 \%$ of median & 0.8 & 2.7 \\
\hline \multirow[t]{3}{*}{ Ireland 87} & $<40 \%$ of median & 0.4 & 1.5 \\
\hline & $<50 \%$ of median & 0.9 & 3.1 \\
\hline & $<60 \%$ of median & 1.6 & 5.8 \\
\hline \multirow[t]{3}{*}{ Italy 86} & $<40 \%$ of median & 0.3 & 1.0 \\
\hline & $<50 \%$ of median & 0.6 & 2.3 \\
\hline & $<60 \%$ of median & 1.2 & 4.4 \\
\hline \multirow{3}{*}{ Luxembourg 85} & $<40 \%$ of median & 0.1 & 0.3 \\
\hline & $<50 \%$ of median & 0.3 & 1.0 \\
\hline & $<60 \%$ of median & 0.7 & 2.3 \\
\hline \multirow[t]{3}{*}{ Netherlands 87} & $<40 \%$ of median & 0.2 & 0.4 \\
\hline & $<50 \%$ of median & 0.4 & 1.0 \\
\hline & $<60 \%$ of median & 0.8 & 2.1 \\
\hline \multirow[t]{3}{*}{ Sweden 87} & $<40 \%$ of median & 0.2 & 0.5 \\
\hline & $<50 \%$ of median & 0.4 & 1.0 \\
\hline & $<60 \%$ of median & 0.7 & 1.8 \\
\hline \multirow[t]{3}{*}{ United Kingdom 86} & $<40 \%$ of median & 0.4 & 1.3 \\
\hline & $<50 \%$ of median & 0.8 & 2.7 \\
\hline & $<60 \%$ of median & 1.4 & 5.0 \\
\hline \multirow[t]{3}{*}{ United States 86} & $<40 \%$ of median & 0.8 & 4.4 \\
\hline & $<50 \%$ of median & 1.5 & 8.0 \\
\hline & $<60 \%$ of median & 2.5 & 12.9 \\
\hline
\end{tabular}

Sources: LIS micro data base; OECD, Annual National Accounts; OECD, Labour Force Statistics; OECD, Social Data base.

Notes: Poverty estimates refer to the whole population, and are based on per-capita income. $<40 \%,<50 \%$, and $<60 \%$ of median refers to persons living in families having less than $40 \%, 50 \%$, and $60 \%$ of median disposable income, respectively. 
48. Table 6 shows Gini coefficients for the population of non-elderly families as a whole as well as for the low-income groups among them. Gini coefficients for all non-elderly families range between 0.22 (Austria) to 0.34 (United States). In more than half of the countries, incomes among families in the lowest income segment (under 40\%) are distributed more unequally than in the other two low-income segments but more equally than for the population as a whole. In the other countries (Austria, Canada, Germany, Italy, Sweden and the United States), the Gini coefficients are similar for all three low-income groups. In the case of families below the $50 \%$-line, we observe that, in general, their incomes are far more equally distributed than those of the entire non-elderly population.

\section{Synthetic poverty indicators: the Sen Index}

49. Summarising the discussion in the preceding sections, we can conclude that the extent of low income in a country depends on:

i) the number (or fraction) of persons/families below a defined low-income standard, as measured by the low-income rate (LIR);

ii) the severity of the low-income situation which can be proxied by the average low-income gap (ALG); and

iii) the distribution of income among the low-income population, proxied by, for instance, the Gini coefficient.

50. Sen (1976) developed an approach to combine these three elements into a single indicator of poverty for a given poverty line. The proposed measure consists of the head-count ratio multiplied by the income-gap ratio augmented by the Gini coefficient of the poor weighted by the ratio of the mean income of the poor to the poverty- line income level. The Sen Index is thus defined in the following way:

$$
\begin{aligned}
\mathrm{S} & =\operatorname{LIR}\left[\mathrm{ALG}+\frac{\bar{y}_{q}}{z} G_{p}\right] \\
& =\operatorname{LIR}\left[\mathrm{ALG}+(1-\mathrm{ALG}) G_{p}\right]
\end{aligned}
$$

where LIR = low-income rate (head-count ratio),

ALG $=$ average low-income gap,

$\bar{y}_{q}=$ average income of the low-income population,

$z \quad=$ poverty line,

$G_{p}=$ Gini coefficient of income inequality among the low-income population 
Table 6: Gini coefficients for non-elderly families

\begin{tabular}{|c|c|c|c|}
\hline & & $\begin{array}{c}\text { Gini coefficient } \\
\text { (all families) }\end{array}$ & $\begin{array}{c}\begin{array}{c}\text { Gini coefficient } \\
\text { (poor) }\end{array} \\
\end{array}$ \\
\hline \multirow[t]{3}{*}{ Australia 85/86 } & $<40 \%$ & \multirow{3}{*}{0.3045} & 0.2373 \\
\hline & $<50 \%$ & & 0.1952 \\
\hline & $<60 \%$ & & 0.1934 \\
\hline \multirow[t]{3}{*}{ Austria 87} & $<40 \%$ & \multirow{3}{*}{0.2153} & 0.1202 \\
\hline & $<50 \%$ & & 0.1187 \\
\hline & $<60 \%$ & & 0.1289 \\
\hline \multirow[t]{3}{*}{ Belgium 85} & $<40 \%$ & \multirow{3}{*}{0.2285} & 0.2385 \\
\hline & $<50 \%$ & & 0.1748 \\
\hline & $<60 \%$ & & 0.1311 \\
\hline \multirow[t]{3}{*}{ Canada 87} & $<40 \%$ & \multirow{3}{*}{0.2995} & 0.1885 \\
\hline & $<50 \%$ & & 0.1890 \\
\hline & $<60 \%$ & & 0.1989 \\
\hline \multirow[t]{3}{*}{ France 84} & $<40 \%$ & \multirow{3}{*}{0.2920} & 0.2343 \\
\hline & $<50 \%$ & & 0.2185 \\
\hline & $<60 \%$ & & 0.1925 \\
\hline \multirow[t]{3}{*}{ Germany $84 / 85$} & $<40 \%$ & \multirow{3}{*}{0.2487} & 0.1431 \\
\hline & $<50 \%$ & & 0.1340 \\
\hline & $<60 \%$ & & 0.1379 \\
\hline \multirow[t]{3}{*}{ Ireland 87} & $<40 \%$ & \multirow{3}{*}{0.3532} & 0.2959 \\
\hline & $<50 \%$ & & 0.1730 \\
\hline & $<60 \%$ & & 0.1567 \\
\hline \multirow[t]{3}{*}{ Italy 86} & $<40 \%$ & \multirow{3}{*}{0.3007} & 0.1631 \\
\hline & $<50 \%$ & & 0.1616 \\
\hline & $<60 \%$ & & 0.1561 \\
\hline \multirow[t]{3}{*}{ Luxembourg 85} & $<40 \%$ & \multirow{3}{*}{0.2363} & 0.2308 \\
\hline & $<50 \%$ & & 0.1513 \\
\hline & $<60 \%$ & & 0.1181 \\
\hline \multirow[t]{3}{*}{ Netherlands 87} & $<40 \%$ & \multirow{3}{*}{0.2555} & 0.2546 \\
\hline & $<50 \%$ & & 0.1971 \\
\hline & $<60 \%$ & & 0.1398 \\
\hline \multirow[t]{3}{*}{ Sweden 87} & $<40 \%$ & \multirow{3}{*}{0.2368} & 0.1392 \\
\hline & $<50 \%$ & & 0.1485 \\
\hline & $<60 \%$ & & 0.1527 \\
\hline \multirow[t]{3}{*}{ United Kingdom 86} & $<40 \%$ & \multirow{3}{*}{0.3018} & 0.2752 \\
\hline & $<50 \%$ & & 0.1907 \\
\hline & $<60 \%$ & & 0.1649 \\
\hline \multirow[t]{3}{*}{ United States 86} & $<40 \%$ & \multirow{3}{*}{0.3394} & 0.2249 \\
\hline & $<50 \%$ & & 0.2326 \\
\hline & $<60 \%$ & & 0.2394 \\
\hline Average (unweighted) & $<40 \%$ & & 0.2112 \\
\hline & $<50 \%$ & 0.2779 & 0.1758 \\
\hline & $<60 \%$ & & 0.1623 \\
\hline
\end{tabular}

Source: LIS micro data base.

Notes: $\quad$ Non-elderly families: Families headed by a person aged less than 60 . Income adjusted for family size (equivalence elasticity $=0.55$ ). Below $40 \%, 50 \%$, and $60 \%$ refers to families having less than $40 \%, 50 \%$, and $60 \%$ of median disposable income, respectively. 
51. In short, the Sen index can be interpreted as a weighted sum of poverty gaps of the poor. The values for the Sen index lie in the closed interval, with $S=0$ if everyone has an income above the poverty line, and $S=1$ if everyone has zero income. Much like many summary statistics of income inequality, the Sen index assumes an ordinal approach to comparisons of welfare?

52. It can be shown that the Sen Index is equal to the low-income rate multiplied by the average low-income gap (LIR * ALG) ${ }^{8}$ in the case of perfect income equality among the low-income population, and equal to the low-income rate (LIR) in the case of perfect inequality:

$$
\begin{array}{ll}
S=L I R * A L G, & \text { for } G_{p}=0 \\
S=L I R, & \text { for } G_{p}=1
\end{array}
$$

In the first case, i.e. when all the poor have the same income, the lower the income of the poor, the closer will S be to LIR; and the larger the proportion of the poor, the closer will S be to ALG.

53. The Sen index is a useful measure for cross-country comparisons of poverty, because it combines the incidence, the intensity and the distribution of low incomes in a single indicator. Traditional measures such as the low-income rate and the average low-income gap fail to capture one or the other of these elements of poverty and provide therefore an incomplete picture when comparing poverty levels across countries. This is particularly important for the analysis of the effects of net taxes and transfers on low-income groups across countries (chapter V.B) since these might result in different (sometimes opposite) changes for one or the other components of poverty.

54. When analysing the results for the Sen indices shown in Table 7, the cross-country patterns derived earlier with the use of the low-income rate and the average low-income gap become more accentuated. We can distinguish four groups of countries:

i) first, the Central European countries -- Austria, Belgium, Germany, Luxembourg and the Netherlands -- with Sen indices significantly below the average, in particular in the $40 \%$ interval;

ii) second, the remaining continental European countries -- France and Italy (together with Germany at the $60 \%$ level) -- which have indices just below the average;

iii) third, the non-continental European countries -- Sweden, Ireland and the United Kingdom -with indices just above the average;

iv) fourth, Australia, Canada and the United States, have very high Sen indices. In particular, the United States has rates more than double the average of all 13 countries.

7. For a discussion of the analytical foundations of the Sen index, see Annex 2.

8. This measure, LIR * ALG, referred to as a poverty index, has sometimes been used as a single poverty indicator (Atkinson 1987; Sen 1976). 
Table 7: Sen poverty index for non-elderly families

\begin{tabular}{|c|c|c|}
\hline & & Sen index*100 \\
\hline \multirow[t]{3}{*}{ Australia 85/86 } & $<40 \%$ of median & 4.38 \\
\hline & $<50 \%$ of median & 6.94 \\
\hline & $<60 \%$ of median & 9.86 \\
\hline \multirow{3}{*}{ Austria 87} & $<40 \%$ of median & 0.98 \\
\hline & $<50 \%$ of median & 2.05 \\
\hline & $<60 \%$ of median & 3.83 \\
\hline \multirow[t]{3}{*}{ Belgium 85} & $<40 \%$ of median & 1.15 \\
\hline & $<50 \%$ of median & 2.06 \\
\hline & $<60 \%$ of median & 3.67 \\
\hline \multirow[t]{3}{*}{ Canada 87} & $<40 \%$ of median & 4.56 \\
\hline & $<50 \%$ of median & 7.05 \\
\hline & $<60 \%$ of median & 10.01 \\
\hline \multirow{3}{*}{ France 84} & $<40 \%$ of median & 2.73 \\
\hline & $<50 \%$ of median & 4.26 \\
\hline & $<60 \%$ of median & 6.47 \\
\hline \multirow[t]{3}{*}{ Germany $84 / 85$} & $<40 \%$ of median & 1.31 \\
\hline & $<50 \%$ of median & 2.86 \\
\hline & $<60 \%$ of median & 5.03 \\
\hline \multirow[t]{3}{*}{ Ireland 87} & $<40 \%$ of median & 3.26 \\
\hline & $<50 \%$ of median & 5.94 \\
\hline & $<60 \%$ of median & 9.08 \\
\hline \multirow[t]{3}{*}{ Italy 86} & $<40 \%$ of median & 2.20 \\
\hline & $<50 \%$ of median & 3.96 \\
\hline & $<60 \%$ of median & 6.54 \\
\hline \multirow[t]{3}{*}{ Luxembourg 85} & $<40 \%$ of median & 0.82 \\
\hline & $<50 \%$ of median & 1.54 \\
\hline & $<60 \%$ of median & 3.03 \\
\hline \multirow[t]{3}{*}{ Netherlands 87} & $<40 \%$ of median & 1.20 \\
\hline & $<50 \%$ of median & 2.01 \\
\hline & $<60 \%$ of median & 3.61 \\
\hline \multirow[t]{3}{*}{ Sweden 87} & $<40 \%$ of median & 4.86 \\
\hline & $<50 \%$ of median & 6.74 \\
\hline & $<60 \%$ of median & 8.88 \\
\hline \multirow[t]{3}{*}{ United Kingdom 86} & $<40 \%$ of median & 3.10 \\
\hline & $<50 \%$ of median & 5.13 \\
\hline & $<60 \%$ of median & 8.03 \\
\hline \multirow[t]{3}{*}{ United States 86} & $<40 \%$ of median & 3.36 \\
\hline & $<50 \%$ of median & 5.27 \\
\hline & $<60 \%$ of median & 7.92 \\
\hline \multirow[t]{3}{*}{ Average (unweighted) } & $<40 \%$ of median & 2.78 \\
\hline & $<50 \%$ of median & 4.54 \\
\hline & $<60 \%$ of median & 6.95 \\
\hline
\end{tabular}

Source: LIS micro data base.

Notes: $\quad$ Non-elderly families: Families headed by a person aged less than 60. Income adjusted for family size (equivalence elasticity $=0.55)$. Sen index $=$ LIR $\left[A L G+(1-A L G) G_{p}\right]$. For definitions of LIR and ALG, see table 4 . 
55. Looking at its decomposition, we see that the high rates of the fourth country group are due mainly to the high incidence of low incomes (expressed in the LIR in table 4); the intensity and distribution of low income in these three countries are close to the average of all countries. This contrasts in particular with the case of the Netherlands, which has a low-income intensity and distribution patterns close to or above the average but below-average low-income incidence which results in a Sen index well below the average. To a lesser degree, the same pattern can be found in France. Another particular case is Ireland, with high low-income incidence (at the 50\% and 60\% level) but well below-average intensity and inequality among the poor; the net result is a Sen index which is not that much in excess of the sample average.

\section{APPLICATION OF RELATIVE POVERTY MEASURES TO INCOME DATA FROM 13 OECD COUNTRIES}

56. This chapter illustrates the use of relative poverty measures -- the low-income rate and the Sen index -- for the purpose of cross-country comparisons. It applies the definitions derived in chapters II, III and IV to micro data on disposable income and market income to assess the effects of net transfers on low income and poverty. Three important caveats should be made at the beginning. First, the data refer to a single year, in the mid to late 1980s. Therefore, nothing can be said about to the dynamics of poverty, i.e. the observation that poverty is a transitory phenomenon for many families ${ }^{9}$. Second, the data fail to capture changes in income-support schemes in recent years. Finally, the data are not fully comparable across countries (see, in particular, Annex 1, section B).

\section{A. Poverty and social expenditures}

57. So far, concepts and measures for poverty based on disposable income have been discussed, examining the relative income positions of families after state intervention through taxes and transfers. There is, however, good reason to believe that public spending influences the level as well as the composition of poverty.

58. By providing health, educational and social services and guaranteeing basic security in the case of old-age, sickness, disability, unemployment and family situation, the welfare state tries to limit the extent of poverty. There are, however, substantive differences across countries in the extent and the generosity of the public social sector. Some studies analyse the relationship between the size of the welfare state and cross-national variations in poverty. Gustafsson/Uusilato (1989: 6), for example, claim that "the bigger the welfare state the smaller is the poverty rate."

59. This hypothesis can be tested with a simple cross-section regression for the 13 countries included in our study. The independent variable, the size of the welfare state, is proxied by total public expenditures on education, pensions, unemployment, health, family and other allowances as a share of GDP. The dependent variable is the low-income rate (50 percent level) for the entire population (i.e. including

9. For a discussion of the dynamics of poverty, see Atkinson (1991). For preliminary results derived from panel studies, see Duncan (1984) for the United States and Deleek et al. (1989) for some European countries 
elderly persons, as old-age pensions are also included in total social expenditures). Chart 2 shows that there is a significant negative correlation between these two variables across countries. The regression equation is

$\mathrm{LIR}=25.8-0.58 * \mathrm{SOC}$,

with $\mathrm{R}^{2}=0.703$, and standard error of coefficient $=0.11$

60. When the dependent variable is defined at the 60 percent income level, the correlation is even stronger:

$\mathrm{LIR}=35.1-0.68 * \mathrm{SOC}$,

with $\mathrm{R}^{2}=0.736$, and standard error of coefficient $=0.12$

Chart 2: Low-income rates and social expenditures

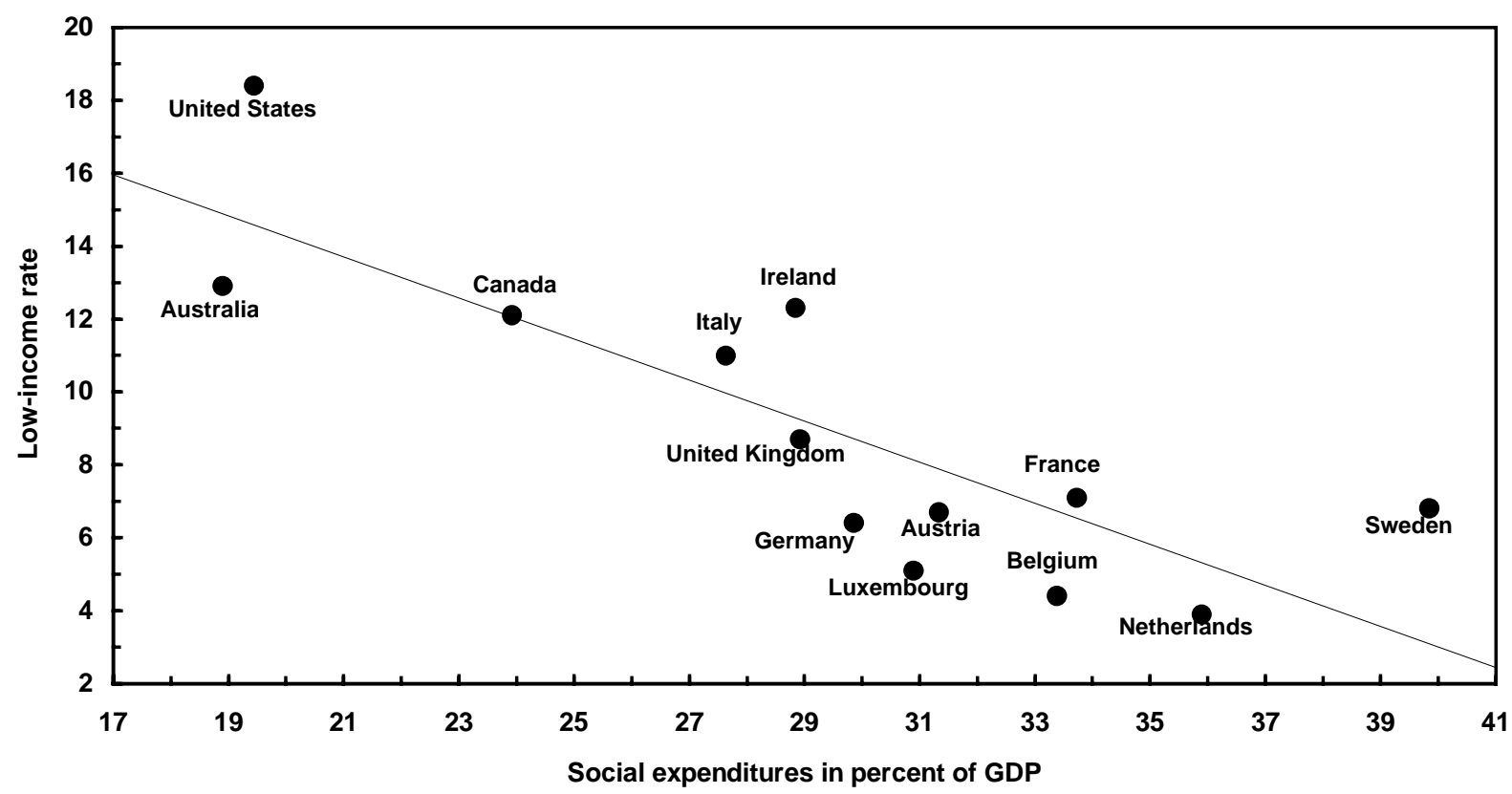

Source: LIS micro data base; OECD Social Data base.

Note: Low-income rate defined as percentage of persons in families with disposable incomes below $50 \%$ of median adjusted disposable income.

61. In both cases, we can distinguish three groups of countries: The United States and Australia both have the highest low-income rate and the lowest social spending as a share of GDP. On the other hand, Sweden and the continental European countries (except Italy) have relatively low poverty rates and high social expenditures. Canada, the United Kingdom, Ireland and Italy lie in between. 


\section{B. The effects of net transfers on relative incomes among non-elderly families}

62. The purpose of the rest of this chapter is to analyse in more detail the net impact of taxes and transfers on poverty among non-elderly families ${ }^{10}$, using the Sen poverty index and its components as set out in chapter IV. Three specific groups in the low-income population are distinguished:

i) all non-elderly families;

ii) non-elderly families with three and more children; and

iii) non-elderly single-parent families.

\section{Overall Sen poverty indices}

63. Poverty for each group is first measured in relation to their market incomes and then compared to poverty measured in terms of disposable incomes. This permits us to analyse the combined effect of income taxes and transfers on low income ${ }^{11}$. A separate assessment of the effects of social transfers alone is not very meaningful as a significant decrease in poverty for a certain population group due to social transfers may partly be offset by a relatively high burden of personal taxation for the same group.

64. The analysis in this chapter covers only ten countries, as estimates of market incomes are not available in the LIS data base for Austria, Italy and Luxembourg. In addition, the estimates for two of the ten countries have to be treated with special care: the results for France (before net transfers) are not fully comparable with the other countries, as social security contributions (unlike in the other countries) are not regarded as part of the personal income tax, and are therefore excluded. Also the results for Sweden are not fully comparable with those of other countries due to a particular unit definition (see Annex 1, section B). For reasons of sensitivity testing, we show poverty estimates for three low-income bands: 40, 50 and 60 percent below the median income level.

65. Table 8 shows Sen indices and rates of reduction in Sen indices, once allowance is made for taxes and transfers, for the afore-mentioned demographic groups. As a first result, it can be seen that in all countries poverty is reduced after accounting for net transfers. This holds true for all three demographic groups in all low-income bands. The reduction rates range from 11 to almost 100 percent.

10. Unfortunately, data availability means that it is only possible to analyse the effects of cash transfers and direct taxes. No income can be imputed for transfers in kind, nor is it possible to adjust for the effects of indirect taxes.

11. Comparing pre-tax and transfer incomes with those post- taxes and transfers assumes away any behavioural responses. In a society without taxes and transfers, there would be more market income at the margin, so the percentage of the population who would in fact be below a given absolute level of incomes without net transfers would be less than the static estimates shown in the paper. On the other hand, this might also change the income distribution through the market. 
Table 8: Sen poverty index before and after taxes and transfers, for three demographic groups

\begin{tabular}{|c|c|c|c|c|c|c|c|c|c|c|}
\hline & & \multicolumn{3}{|c|}{$\begin{array}{c}\text { BEFORE TAXES AND } \\
\text { TRANSFERS }\end{array}$} & \multicolumn{3}{|c|}{$\begin{array}{c}\text { AFTER TAXES AND } \\
\text { TRANSFERS }\end{array}$} & \multicolumn{3}{|c|}{$\begin{array}{l}\text { REDUCTION IN SEN } \\
\text { INDEX }\end{array}$} \\
\hline & & $\begin{array}{c}\text { All } \\
\text { families }\end{array}$ & $\begin{array}{l}\text { Families } \\
\text { with } 3+ \\
\text { children }\end{array}$ & $\begin{array}{c}\text { Single- } \\
\text { parent } \\
\text { families }\end{array}$ & $\begin{array}{c}\text { All } \\
\text { families }\end{array}$ & $\begin{array}{l}\text { Families } \\
\text { with } 3+ \\
\text { children }\end{array}$ & $\begin{array}{c}\text { Single- } \\
\text { parent } \\
\text { families }\end{array}$ & $\begin{array}{c}\text { All } \\
\text { families }\end{array}$ & $\begin{array}{l}\text { Families } \\
\text { with } 3+ \\
\text { children }\end{array}$ & $\begin{array}{c}\text { Single- } \\
\text { parent } \\
\text { families }\end{array}$ \\
\hline \multirow[t]{3}{*}{ Australia 85/86 } & $<40 \%$ & 12.0 & 13.9 & 51.7 & 4.4 & 7.2 & 15.7 & $63.5 \%$ & $48.2 \%$ & $69.6 \%$ \\
\hline & $<50 \%$ & 13.3 & 16.0 & 53.6 & 6.9 & 11.3 & 24.7 & $47.9 \%$ & $29.2 \%$ & $53.9 \%$ \\
\hline & $<60 \%$ & 14.7 & 18.3 & 55.4 & 9.9 & 16.6 & 32.1 & $32.9 \%$ & $9.5 \%$ & $42.0 \%$ \\
\hline \multirow[t]{3}{*}{ Belgium 85} & $<40 \%$ & 7.8 & 7.1 & 23.3 & 1.2 & 1.0 & 5.1 & $85.2 \%$ & $86.0 \%$ & $78.2 \%$ \\
\hline & $<50 \%$ & 8.7 & 11.7 & 27.2 & 2.1 & 2.3 & 8.0 & $76.4 \%$ & $80.6 \%$ & $70.5 \%$ \\
\hline & $<60 \%$ & 10.3 & 18.0 & 31.0 & 3.7 & 5.2 & 12.7 & $64.4 \%$ & $71.3 \%$ & $58.9 \%$ \\
\hline \multirow[t]{3}{*}{ Canada 87} & $<40 \%$ & 10.1 & 13.4 & 40.0 & 4.6 & 4.6 & 13.4 & $54.8 \%$ & $65.9 \%$ & $66.5 \%$ \\
\hline & $<50 \%$ & 12.0 & 16.6 & 43.6 & 7.1 & 8.5 & 21.0 & $41.4 \%$ & $49.0 \%$ & $51.9 \%$ \\
\hline & $<60 \%$ & 14.3 & 19.7 & 47.6 & 10.0 & 13.3 & 28.4 & $30.1 \%$ & $32.5 \%$ & $40.3 \%$ \\
\hline \multirow[t]{3}{*}{ France 84} & $<40 \%$ & 8.1 & 17.4 & 23.5 & 2.7 & 1.7 & 5.3 & $66.3 \%$ & $90.5 \%$ & $77.6 \%$ \\
\hline & $<50 \%$ & 10.8 & 24.1 & 27.8 & 4.3 & 3.5 & 8.5 & $60.7 \%$ & $85.6 \%$ & $69.6 \%$ \\
\hline & $<60 \%$ & 14.0 & 31.0 & 34.2 & 6.5 & 7.0 & 13.4 & $53.7 \%$ & $77.5 \%$ & $60.8 \%$ \\
\hline \multirow[t]{3}{*}{ Germany $84 / 85$} & $<40 \%$ & 8.9 & 8.0 & 33.9 & 1.3 & 2.1 & 6.9 & $85.3 \%$ & $73.3 \%$ & $79.7 \%$ \\
\hline & $<50 \%$ & 9.8 & 9.6 & 37.1 & 2.8 & 4.3 & 12.8 & $71.0 \%$ & $55.1 \%$ & $65.5 \%$ \\
\hline & $<60 \%$ & 10.9 & 13.0 & 39.0 & 5.0 & 8.0 & 19.3 & $53.9 \%$ & $39.0 \%$ & $50.6 \%$ \\
\hline \multirow[t]{3}{*}{ Ireland 87} & $<40 \%$ & 18.3 & 21.9 & 37.8 & 3.3 & 3.1 & 8.2 & $82.1 \%$ & $85.7 \%$ & $78.3 \%$ \\
\hline & $<50 \%$ & 19.8 & 23.8 & 38.1 & 5.9 & 6.7 & 13.8 & $70.0 \%$ & $71.7 \%$ & $63.7 \%$ \\
\hline & $<60 \%$ & 21.6 & 26.2 & 40.4 & 9.1 & 11.1 & 19.2 & $57.9 \%$ & $57.7 \%$ & $52.4 \%$ \\
\hline \multirow[t]{3}{*}{ Netherlands 87} & $<40 \%$ & 11.1 & 8.8 & 47.9 & 1.2 & 2.4 & 4.6 & $89.2 \%$ & $73.0 \%$ & $90.4 \%$ \\
\hline & $<50 \%$ & 11.7 & 9.9 & 44.5 & 2.0 & 4.1 & 6.6 & $82.8 \%$ & $58.6 \%$ & $85.2 \%$ \\
\hline & $<60 \%$ & 12.1 & 15.7 & 47.4 & 3.6 & 8.5 & 10.9 & $70.2 \%$ & $46.2 \%$ & $76.9 \%$ \\
\hline \multirow[t]{3}{*}{ Sweden 87} & $<40 \%$ & 11.2 & 8.8 & 29.3 & 3.4 & 0.7 & 1.0 & $70.1 \%$ & $92.5 \%$ & $96.6 \%$ \\
\hline & $<50 \%$ & 13.3 & 11.3 & 28.2 & 5.3 & 1.2 & 2.0 & $60.2 \%$ & $89.2 \%$ & $92.9 \%$ \\
\hline & $<60 \%$ & 15.5 & 13.9 & 33.1 & 7.9 & 2.2 & 4.0 & $49.0 \%$ & $84.1 \%$ & $87.8 \%$ \\
\hline \multirow[t]{3}{*}{ United Kingdom 86} & $<40 \%$ & 17.2 & 26.4 & 59.2 & 3.1 & 4.4 & 4.5 & $82.0 \%$ & $83.2 \%$ & $92.4 \%$ \\
\hline & $<50 \%$ & 18.4 & 28.4 & 61.2 & 5.1 & 8.5 & 9.0 & $72.1 \%$ & $70.0 \%$ & $85.3 \%$ \\
\hline & $<60 \%$ & 19.6 & 30.8 & 63.5 & 8.0 & 14.1 & 16.7 & $59.0 \%$ & $54.4 \%$ & $73.7 \%$ \\
\hline \multirow[t]{3}{*}{ United States 86} & $<40 \%$ & 11.1 & 20.7 & 39.2 & 7.1 & 13.1 & 21.9 & $35.6 \%$ & $36.8 \%$ & $44.2 \%$ \\
\hline & $<50 \%$ & 13.0 & 24.0 & 42.9 & 10.0 & 19.1 & 29.9 & $22.8 \%$ & $20.6 \%$ & $30.3 \%$ \\
\hline & $<60 \%$ & 15.1 & 27.5 & 46.8 & 13.2 & 24.4 & 36.5 & $12.3 \%$ & $11.2 \%$ & $22.0 \%$ \\
\hline \multirow{3}{*}{ Average } & $<40 \%$ & 11.6 & 14.6 & 38.6 & 3.2 & 4.0 & 8.6 & $72.2 \%$ & $72.5 \%$ & $77.6 \%$ \\
\hline & $<50 \%$ & 13.1 & 17.5 & 40.4 & 5.2 & 6.9 & 13.6 & $60.6 \%$ & $60.4 \%$ & $66.3 \%$ \\
\hline & $<60 \%$ & 14.8 & 21.4 & 43.8 & 7.7 & 11.0 & 19.3 & $48.1 \%$ & $48.5 \%$ & $55.9 \%$ \\
\hline
\end{tabular}

Source: LIS micro data base.

Notes: $\quad$ Data refer to non-elderly families, i.e. families headed by a person aged less than 60. Income adjusted for family size (equivalence elasticity $=0.55$ ). Below $40 \%, 50 \%$, and $60 \%$ refer to families having less than $40 \%, 50 \%$, and $60 \%$ of median disposable income, respectively. Sen index multiplied by 100 .

66. A second finding from Table $\mathbf{8}$ is, that the rank ordering of countries changes when allowance is made for taxes and transfers. A third general result is that the differences in the levels of Sen indices between low-poverty and high-poverty countries are much larger after accounting for net transfers than before. Both findings imply that poverty is reduced in some countries more than in others by workings of the tax and transfer system. 
67. Analysis of poverty across the three different demographic groups shows that, in general, poverty among single parents is significantly higher than among families with three or more children which, in turn, have higher poverty levels than all non-elderly families. This picture does not change when allowance is made for net transfers. There are, however, some notable exceptions: in Germany and the Netherlands, families with three or more children show the lowest Sen indices across the three demographic groups, before accounting for net transfers (but not thereafter). The same is true for France, but only after accounting for net transfers. In Sweden, Sen indices for families with three or more children are lowest before and after net transfers, and Sen indices for single-parent families are lower than for all non-elderly families after net transfers. In the following, country-specific poverty patterns for the three demographic groups are discussed separately.

\section{All non-elderly families (Columns 1 and 4, Table 8)}

68. Looking at the absolute values of $\mathrm{S}$ for market incomes, we observe that poverty in all three low-income segments is highest in Ireland and the United Kingdom, and lowest in Belgium, France and Germany. Once allowance is made for taxes and transfers, the United States, Canada and Australia have the highest values for S, and Belgium, the Netherlands and Germany the lowest values. High reduction rates for $\mathrm{S}$ are observed for the following countries: the Netherlands, Belgium, Ireland, the United Kingdom and Germany. The smallest reduction is in the United States. These findings are summarised in Chart 3 which shows the relative positions of countries before and after taxes and transfers for Sen indices at the 50 percent income level.

69. Not surprisingly, all countries reduce poverty levels more for the lowest income group than for those in the higher segments. However, Australia and the United States, countries where means-testing plays a major role in their social protection systems, reduce poverty in the lowest income segment by two to three times more than for families in the $60 \%$-segment. On the other hand, France, the Netherlands and Sweden reduce poverty levels in all three segments to about the same extent. 
Chart 3: Sen-index before and after allowance for net transfers, non-elderly families

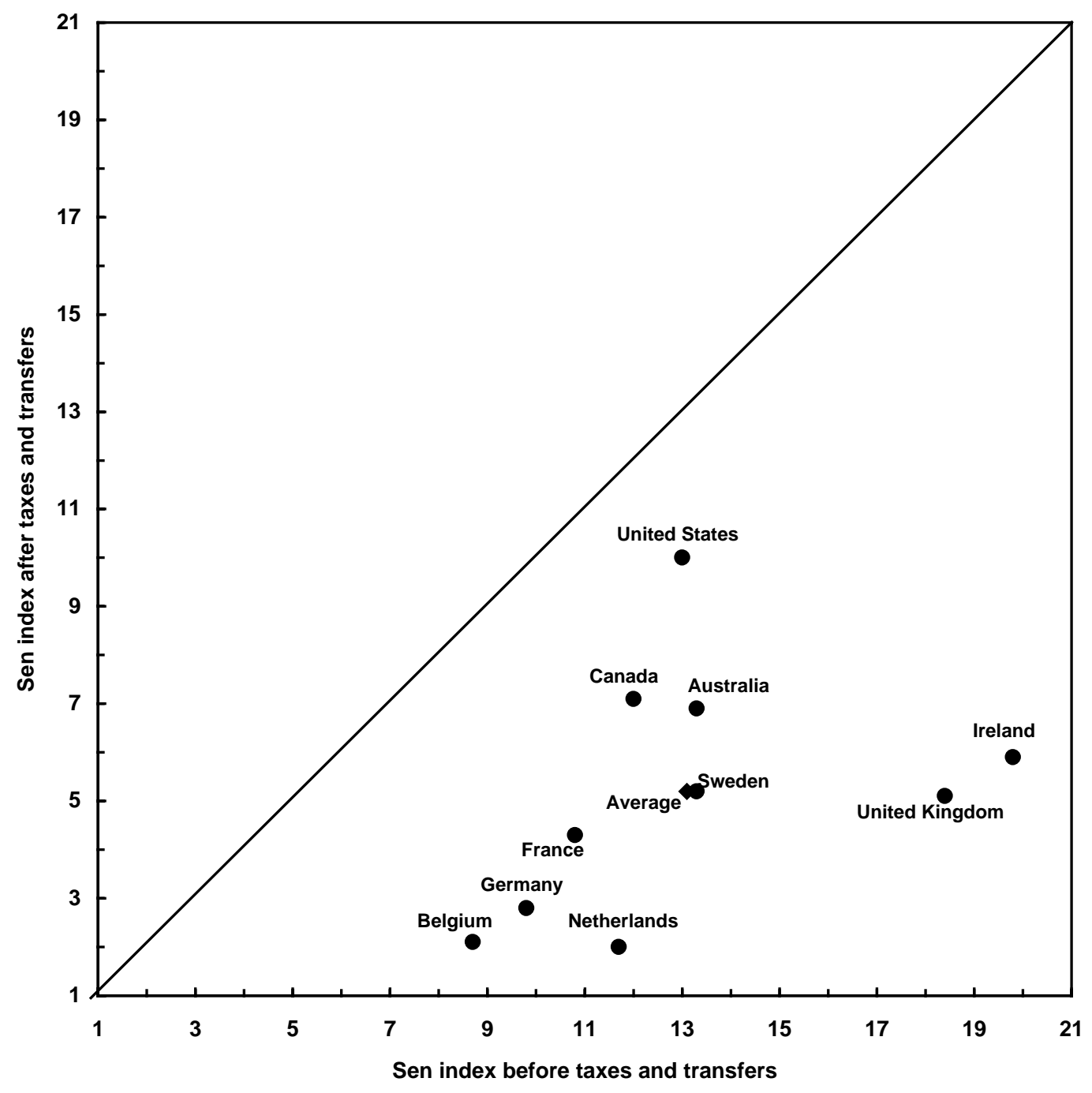

Source: LIS micro data base

Note: $\quad$ Sen indices at the 50 per cent cut-off level. Average: unweighted country sample average.

Families with three children or more (Columns 2 and 5, Table 8)

70. Germany and the Netherlands have the lowest pre-tax and transfer poverty values for S, Ireland, the United States and the United Kingdom the highest ones. When allowance is made for taxes and transfers, poverty levels for families with three children or more move in some countries closer to or below the average for all non-elderly families; this is the case in Belgium, Canada, France, Ireland and the United Kingdom. In Sweden, poverty levels for families with three children or more stay below the average for all families. 
71. Concerning the absolute poverty levels for families with three or more children after taxes and transfers, we can distinguish three country groups: the continental European and Scandinavian countries with Sen values well below average; a four-country group comprising Canada, Australia, Ireland and the United Kingdom (values around average); and the United States with Sen indices far above the average across all countries.

72. The highest reduction rates for $\mathrm{S}$ for families with three or more children can be observed for Sweden, France, Belgium and the United Kingdom. Among these countries, Belgium, Sweden and the United Kingdom have low poverty levels for families with three or more children already before taxes and transfers.

\section{Single-parent families (Columns 4 and 7, Table 8)}

73. The highest reduction rates for $\mathrm{S}$ can be observed in Sweden, the United Kingdom and the Netherlands. In particular, poverty of single parents in Sweden, measured in terms of disposable income, is well below the overall average. The United Kingdom and the Netherlands, although having the highest Sen values before taxes and transfers (together with Australia), have poverty levels close to the cross-country average after accounting for net transfers.

74. On the other hand, reduction rates for $\mathrm{S}$ are the lowest across countries in the United States, Australia and Canada. These countries also experienced the most significant increase of single-parent families within the total population in the 1980s (OECD 1990a).

\section{Components of poverty and poverty reduction}

75. This sub-section seeks to quantify the respective weights that can be attributed to the reduction of the following dimensions of poverty:

i) its incidence (the low-income rate);

ii) its intensity (the low-income gap); and

iii) the degree of income inequality among the poor.

76. The respective values are shown in Annex 3, Table A.6 (all non-elderly families), Table A.7 (families with three or more children) and Table A.8 (single parents). The question is whether there are country-specific patterns to be observed concerning the relative importance of the three components of poverty reduction. If, for example, net transfers result in a reduction of the low-income gap and the income inequality among the poor but not in a reduction of the low-income rate, this may indicate a certain targeting to the poorest sections of the population. If, on the other hand, the low-income rate decreases at the same time as intensity and income inequality among the poor increases, this may suggest that net transfers have mainly been allocated to the better-off among the poor.

77. The evidence from the LIS data sets suggests that targeting of net transfers to the poorest segments seems to be strongest in Australia, Canada and the United States and, to a lesser degree, in Germany, Ireland and the United Kingdom. There is no clear pattern to be observed for the remaining countries.

78. The highest rates of reduction of the Sen index were observed for the Netherlands (for all non-elderly families) and for Sweden (families with three or more children and single-parents). In both countries, each of the components of poverty is reduced substantially in all three low-income segments. 
79. The effects of net transfers on the various components of poverty differ between all non-elderly families on the one hand and the two specific population groups on the other. Before adjusting for net transfers, all three components of poverty (except the intensity and income inequality among the poor in the case of families with three or more children) are, on average, higher for the two specific population groups than for all families. After allowing for net transfers, poverty incidence for the two specific population groups is still significantly higher than for all non-elderly families; however, this is not the case for the intensity of poverty (the low-income gaps are slightly lower), and even less for income inequality (Gini coefficients are about $10 \%$ lower).

\section{Child poverty and its elements}

80. This section analyses child poverty before and after net transfers using the Sen poverty index. For this exercise, the reference population is confined to children instead of families ${ }^{12}$. Children are defined here as unmarried persons under age 18 , living in the family.

\section{Low-income rates}

81. First, the percentages of children below two of the income cut-off lines (40\% and $50 \%$ below the median disposable income) are analysed and compared with the ratios for the whole population and across countries. Chart 4 shows that child poverty is, in general, lower than adults' poverty except for the United States (at both low-income levels) and Canada (in the 50\% segment) but also for Australia and three European countries when moving to lower income segments: Ireland, Italy and the United Kingdom. In particular in countries with high rates of child poverty one of the current policy questions refers to a possible targeting of transfer policies to 'children at risk'.

\section{Overall Sen poverty indices and components for children}

82. Chart 5 compares Sen indices for children before and after taxes and transfers. Child poverty before taxes and transfers, as measured by S, is highest in Ireland and in the United Kingdom and lowest in Germany. Once allowance is made for taxes and transfers, overall child poverty based on the disposable income of their families is lowest in Belgium, Germany, and Sweden and highest in the United States.

83. A comparison of Chart 5 with Chart 3 (Sen indices for all non-elderly families) shows roughly the same cross-country patterns: Ireland and the United Kingdom are one pair of 'outliers' (very high pre-tax and transfer values of the Sen index and average post-tax and transfer values) and the three non-European countries are another (average pre-tax and transfer values of the Sen index and high post-tax and transfer values).

12. Technically, the population of children is 'reconstructed' by multiplying the household sample weights by the number of children in each family. 
Chart 4: Percentages of persons with of low incomes

A. Persons below $50 \%$ of median income

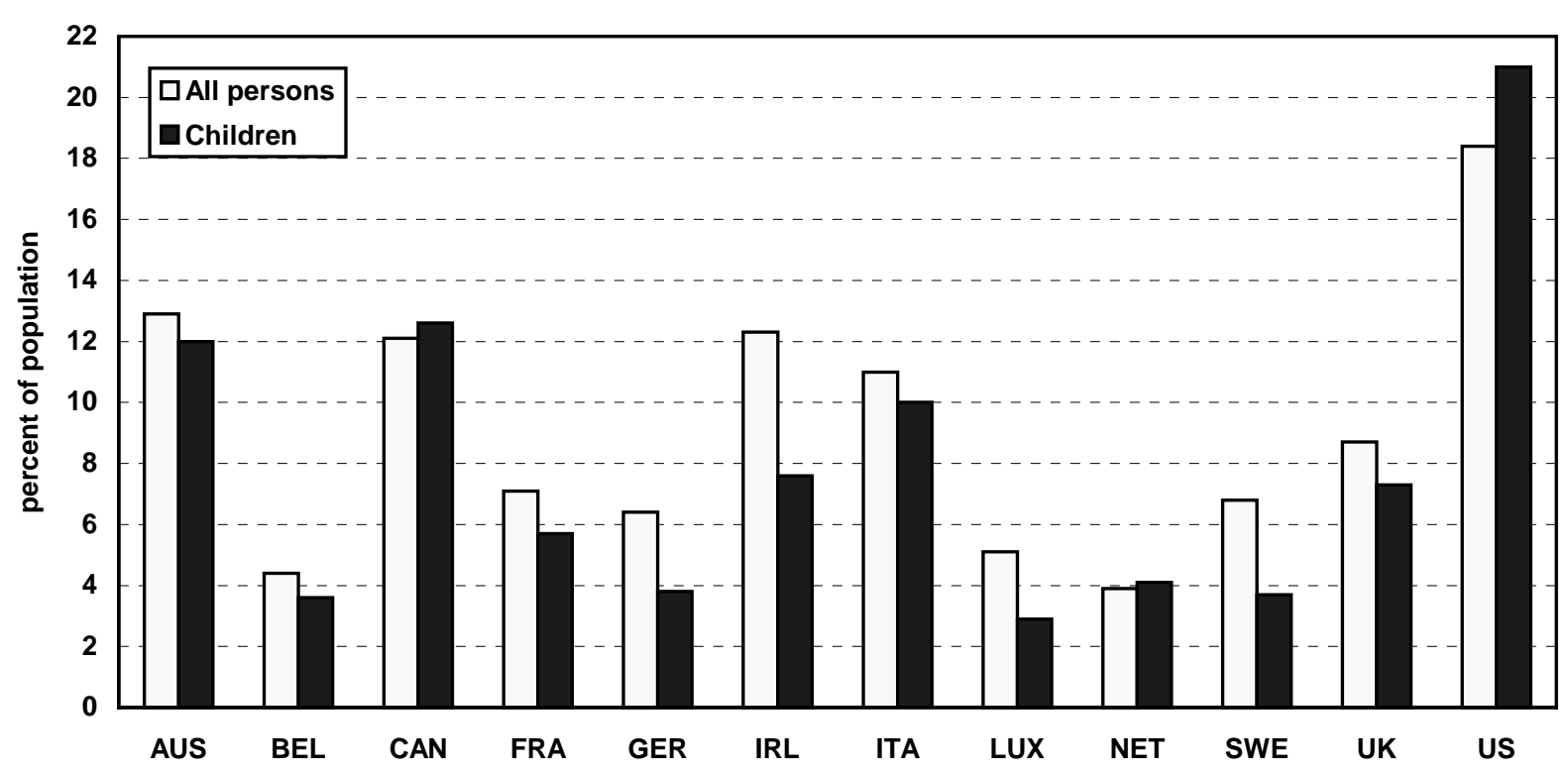

B. Persons below $40 \%$ of median income

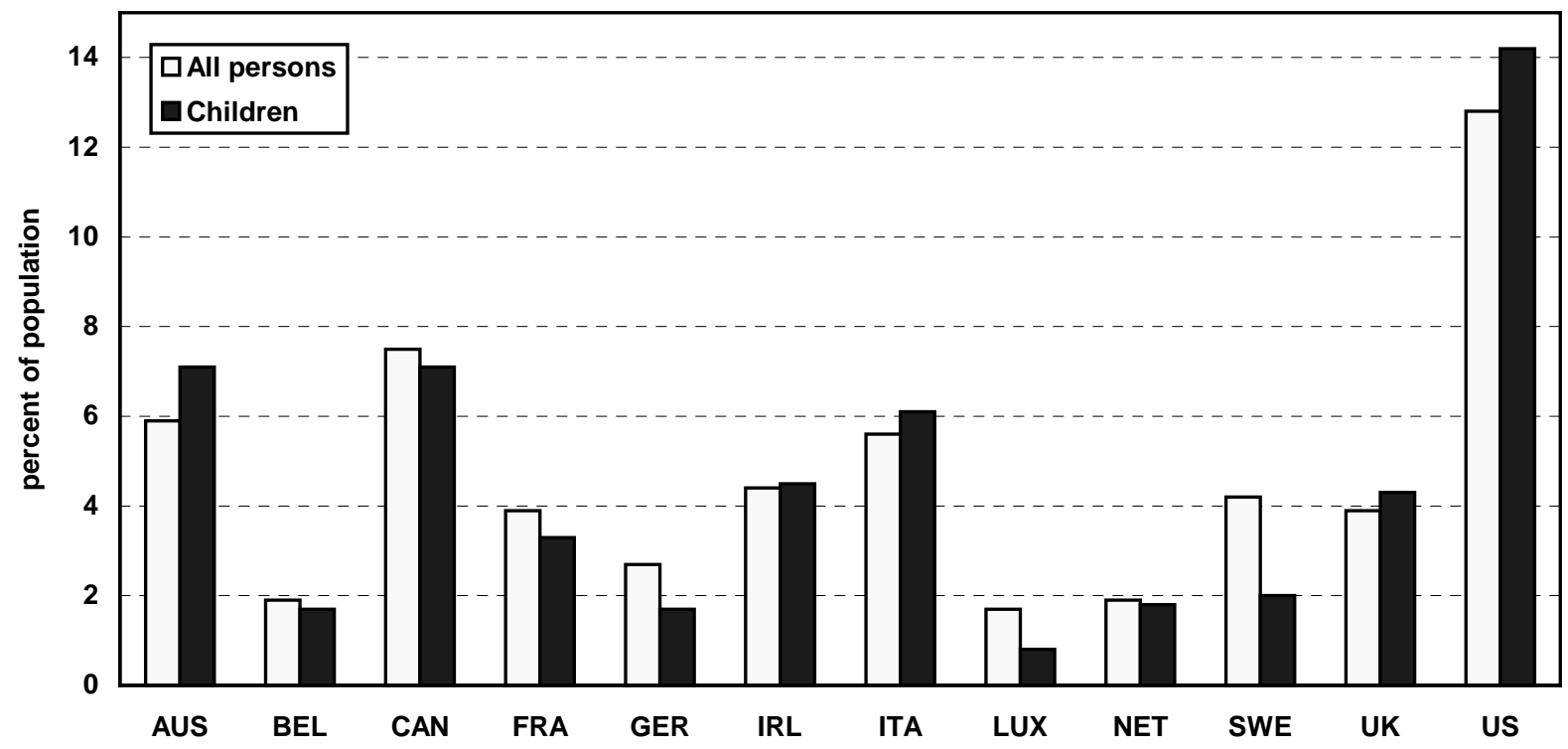

Source: LIS micro data base

Note: Low-income rate defined as percentage of persons in families with disposable incomes below 40 and $50 \%$ of median adjusted disposable income, respectively. 


\section{Chart 5: Sen-index before and after allowance for net transfers, children living in poor families}

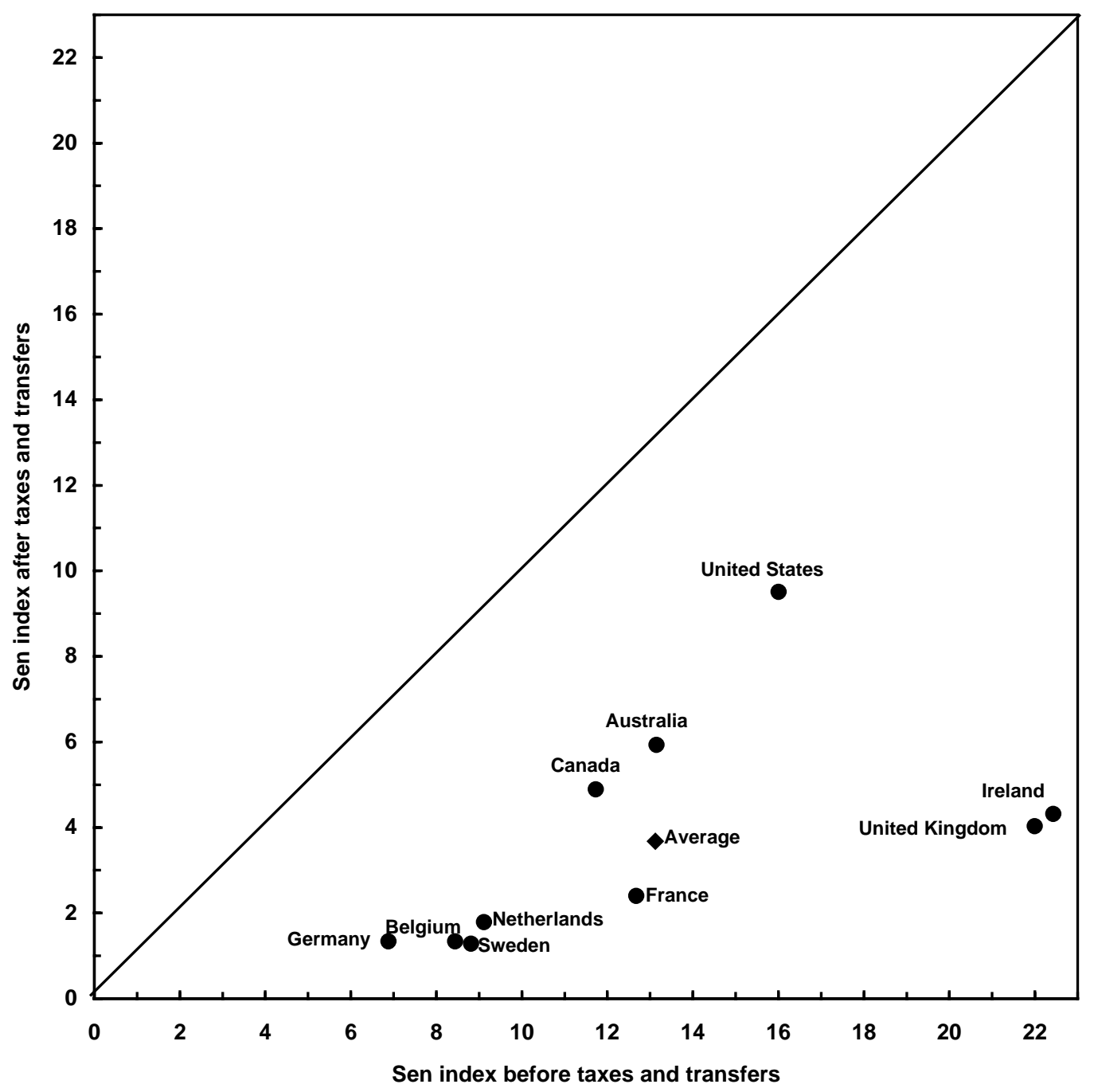

Source: LIS micro data base

Note: $\quad$ Sen indices at the 50 per cent cut-off level. Average: unweighted country sample average.

84. The various components of poverty -- incidence, intensity and income inequality -- are shown separately in Table A.9 in Annex 3. In Belgium and France, the relatively high incidence of pre-transfer child poverty is 'counteracted' by a small income gap and a more equal distribution of family income among poor children, resulting in below-average Sen poverty indices. In both countries, a relatively large number of children are poor (the low-income rates are in fact close to or higher than in the United States), but the market incomes of their families are more equally distributed and are much closer to the low-income line.

85. As for child poverty measured after transfers, the high incidence of such poverty in Canada is partly offset by a relatively small income gap and one of the most equal income distributions among the families of poor children across countries. On the other hand, Australia and, in particular, Ireland and the 
United Kingdom (which have below-average poverty rates for children in the $40 \%$ and $50 \%$ segments) have the highest income gaps and a high concentration of low incomes after taxes and transfers, resulting in above-average values of the Sen index for child poverty.

86. When comparing the effects of net transfers on the income position of children with those for all families (Table 8), it can be seen that the poverty reduction (measured by the decline in the Sen index) is higher for children in all countries, especially in Canada, France, Sweden and the United States. In all European countries, the reduction of child poverty (measured by the decline in S) is higher than in the United States. Canada's and Australia's reduction rates lie in between.

\section{SUMMARY AND CONCLUSIONS}

87. This paper focuses on the definition and measurement of low income and poverty from the explicit perspective of international comparisons, using micro data for 13 OECD countries from the Luxembourg Income Study (LIS). Although economic analysis of poverty and social well-being is ultimately interested in consumption and consumption behaviour, disposable income was selected as a single indicator for well-being. Ideally, this income measure should include income in-kind, but this was impossible with the data used in this paper (except for certain transfer incomes in-kind).

88. Three different approaches to defining and measuring poverty were discussed: absolute, relative and subjective approaches. For the purpose of international cross-country comparisons, the most suitable approach was judged to be the economic distance approach. According to this concept, poverty is defined as a fraction of the median disposable income, using low-income bands rather than a single cut-off line. Three such bands were used in this paper, covering 40, 50 and 60 percent, respectively, of the median income.

89. It was decided to adjust disposable income for family size. Alternative equivalence scales have been used in the literature and some sensitivity tests were undertaken. For the purpose of this paper, a 'policy-based' equivalence scale was selected, based on adjustment factors for family size implicit in many OECD countries' social programmes.

90. The analysis focused on non-elderly families (families with a household head aged less than 60) and, among them, specific population groups at risk: families with three children or more and single-parent families.

91. The data used in this paper refer to low incomes and poverty in OECD countries around the middle to late $1980 \mathrm{~s}$, reflecting the results of policies and the labour market situation at that time. Hence, the results may not be a good indication of the current situation in these countries. For example, many countries have modified their tax and transfer policies precisely with the aim of coping with problems of insufficient resources among particular population groups (such as the introduction of the RMI in France in 1988, or specific family policies in Australia and the United Kingdom). Nonetheless, the analysis revealed some interesting cross-country patterns. 
92. Concerning the overall picture of poverty -- as measured by relative disposable income -- among non-elderly families as well as for most of the specific population groups at risk analysed in the paper, the United States and, to a lesser extent, Australia, Canada and Ireland had poverty indicators above the sample average. On the other hand, poverty was lowest among some Central European countries -Austria, Belgium, Luxembourg, and the Netherlands.

93. At a first glance, the size of the welfare state appears to be negatively correlated with the level of poverty across the countries studied. Social transfers constitute an important part of income for non-elderly families, particularly in some European countries. In order to assess the combined effects of taxes and transfers on incomes, the analysis compared poverty, as measured by market income, with poverty, as measured by disposable income. This comparison revealed, that net transfers result, in general, in a reduction of poverty: low-income rates when measured in terms of disposable income are -- in some countries substantially -- lower than when measured in terms of market income.

94. The paper applied the Sen poverty index to micro data on incomes of non-elderly families, families with three or more children, single parents, and children. In all countries and for all population groups, overall poverty was reduced once allowance is made for net transfers. High poverty reduction rates, measured by the decline in the value of the Sen index, were observed for all European countries and low ones for the United States. Poverty reduction rates in Australia and Canada were relatively low but closer to the average.

95. Analysis of poverty among these specific groups across countries revealed that relatively large amounts of net transfers devoted to certain vulnerable groups (e.g. single parents) shielded an important proportion of these families from the risk of poverty. However, this conclusion remains preliminary, since the poverty estimates in this paper were not corrected for the effects of indirect taxes on the incidence and composition of poverty. Further research is needed to correct for this omission, e.g. by imputing indirect taxes in income estimates using consumption patterns for specific families from national household budget surveys.

96. The Sen index allows for the decomposition of poverty into three components: its incidence (measured by the low-income rate), intensity (proxied by the low-income gap) and income distribution (proxied by the Gini coefficient). In general, net transfers in the three non-European countries resulted primarily in a reduction of the low-income gap and inequality among the poor. On the other hand, in some European countries -- Belgium, France, and the Netherlands -- the reduction of poverty after accounting for net transfers was mainly due to a reduction in the incidence of poverty, i.e. the number of poor families. For specific groups at risk (families with three children or more and single parents), net transfers resulted in some countries -- Sweden, Ireland and the United Kingdom -- in an equally high reduction of all three components of poverty. 


\section{ANNEX 1: THE LUXEMBOURG INCOME STUDY (LIS)}

97. This Annex describes the surveys stored at the Luxembourg Income Study which have been used for the analysis, the structure of the demographic and income variables and presents the derived poverty lines in national currencies. Section B discusses data limitations and quality, such as coverage and non-response rates.

\section{A. The LIS data base b $^{13}$}

98. By early 1993, 40 data files are stored at LIS, covering 17 countries, of which 15 are OECD member countries. For some countries, up to three "data rounds" are covered. The quantitative analysis in this paper has been limited to the countries from the most recent data round, reflecting the focus on cross-country comparisons rather than comparisons over time. Table A.1 shows the OECD countries in the LIS data base, their reference year for the most recent data round, and the underlying national household survey.

Table A.1: Surveys used for "second-round" LIS data files

(unweighted household sample size in parenthesis)

\begin{tabular}{|c|c|}
\hline Australia 1985/86 & Income Distribution Survey (7563) \\
\hline Austria 1987 & Mikrozensus (11147) \\
\hline Belgium 1985 & The Living Conditions of Households in 1985 (6471) \\
\hline Canada 1987 & Survey of Consumer Finances (10999) \\
\hline France 1984 & Revenus Fiscaux (11044) \\
\hline Germany 1984/85 & $\begin{array}{l}\text { Das sozio-ökonomische Panel, Welle 1/Welle } 2 \text { (Socio-economic Panel Study, } \\
\text { Wave 1/Wave 2) (5174) }\end{array}$ \\
\hline Ireland 1987 & Survey of Income Distribution (3297) \\
\hline Italy 1986 & $\begin{array}{l}\text { Indagine Campionaria sui Bilanci Delle Famiglie (Bank of Italy Income } \\
\text { Survey) (8022) }\end{array}$ \\
\hline Luxembourg 1985 & $\begin{array}{l}\text { Panel Socio-Economique "Liewen zu Letzebuerg" (Luxembourg Household } \\
\text { Panel Study) (2012) }\end{array}$ \\
\hline Netherlands 1987 & Aanvullend Voorziengengebruik Onderzoek (4833) \\
\hline Sweden 1987 & Inkomstfördelningsundersokningen (Income Distribution Survey) (9421) \\
\hline United Kingdom 1986 & The Family Expenditure Survey (6795) \\
\hline United States 1986 & March Current Population Survey (11614) \\
\hline
\end{tabular}

13. For an exhaustive description of the Luxembourg Income Study project, see OECD (1994, forthcoming). 


\section{LIS variable structure}

99. The LIS data files consist of micro data collected by member countries through household surveys. At the household (family) level, there are more than 100 socio-demographic and 50 income variables available for each household in each country. The demographic variables include information such as number and ages of persons, of earners, of children in the household, geographic location etc. The income variables refer to the household (family). Total gross income is defined as market income plus social and private transfers. Disposable income is defined as gross income minus income tax and mandatory social security contributions. Chart A.1 illustrates the relations between the different aggregates.

100. The derived median equivalent disposable incomes are used to calculate the poverty estimates. In general, the paper uses three poverty lines: below 40 percent of the median income ('very poor'), below 50 percent ('poor') and below 60 percent ('near poverty'). For sensitivity testing, three different equivalent scales, in addition to per capita income and unadjusted family income, have been used to adjust the income measures: EQ1 (referring to an equivalence elasticity of 0.33), EQ2 (equivalence elasticity of 0.55) and EQ3 (equivalence elasticity of 0.73) (see chapter III). Table A.2 shows the respective poverty lines for the three equivalence scales, on a per capita and on a family basis, in national currencies. 


\section{Chart A.1: Structure of LIS income variables}

Gross wage and salaries $+$

Farm self-employment income $+$

total earnings

Nonfarm self-employment income

$+$

Cash property income

Sick pay ${ }^{+}$

Accident pay

$+$

Disability pay

$+$

social retirement benefits $+$

child or family allowances $+$

unemployment compensation $+$

maternity pay

$+$

military/veteran/war benefits

$+$

Other social insurance

$+$

Means tested cash benefits

$\stackrel{+}{\text { Near cash benefits }}$
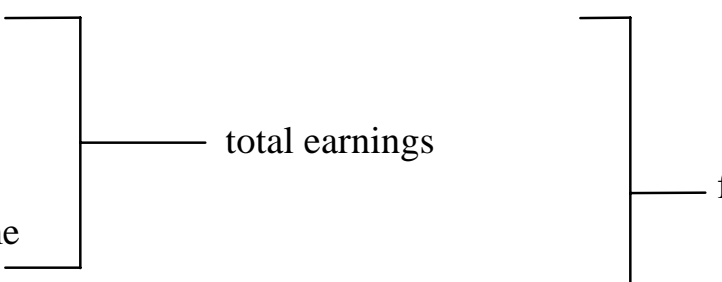

factor income

$+$

Private pensions

$+$

Public sector pensions

$+$

Alimony or child support

$+$

Other regular private income

$+$

Other cash income

means-tested income

\section{Total gross income}

Market income $=$

factor income + occupational pensions

Disposable income $=$ gross income - mandatory contributions for self-employed - income tax mandatory employee contributions 
Table A.2: Poverty lines in national currencies, for three different equivalence scales

\begin{tabular}{|c|c|c|c|c|c|}
\hline & & $\begin{array}{l}\text { non-elderly } \\
\text { families } \\
\text { EQ 2 } \\
\end{array}$ & all persons & all persons & all persons \\
\hline \multirow{3}{*}{$\begin{array}{l}\text { Australia 85/86 } \\
\text { Australian Dollars }\end{array}$} & $<40 \%$ & 4860.0 & 5648.0 & 4352.2 & 3495.4 \\
\hline & $<50 \%$ & 6075.0 & 7060.0 & 5440.3 & 4369.2 \\
\hline & $<60 \%$ & 7290.0 & 8471.9 & 6528.4 & 5243.0 \\
\hline \multirow{3}{*}{$\begin{array}{l}\text { Austria } 87 \\
\quad \text { Austrian Schillings }\end{array}$} & $<40 \%$ & 63465.1 & 77941.4 & 61600.0 & $\overline{51541.4}$ \\
\hline & $<50 \%$ & 79331.4 & 97426.7 & 77000.0 & 64426.8 \\
\hline & $<60 \%$ & 95197.6 & 116912.0 & 92400.0 & 77312.1 \\
\hline \multirow{3}{*}{$\begin{array}{l}\text { Belgium } 85 \\
\text { Hundred Belgian Francs }\end{array}$} & $<40 \%$ & 1462.2 & 1822.7 & 1393.4 & 1128.8 \\
\hline & $<50 \%$ & 1827.8 & 2278.4 & 1741.7 & 1411.1 \\
\hline & $<60 \%$ & 2193.4 & 2734.0 & 2090.0 & 1693.3 \\
\hline \multirow{3}{*}{$\begin{array}{r}\text { Canada } 87 \\
\quad \text { Canadian Dollars }\end{array}$} & $<40 \%$ & 6949.4 & 8636.4 & 6678.1 & $\overline{5384.9}$ \\
\hline & $<50 \%$ & 8686.7 & 10795.6 & 8347.6 & 6731.2 \\
\hline & $<60 \%$ & 10424.0 & 12954.7 & 10017.1 & 8077.4 \\
\hline \multirow{3}{*}{$\begin{aligned} \text { France } 84 & \\
& \text { Fren }\end{aligned}$} & $<40 \%$ & 24170.2 & 29889.6 & 23125.8 & $\overline{18938.9}$ \\
\hline & $<50 \%$ & 30212.8 & 37362.0 & 28907.2 & 23673.6 \\
\hline & $<60 \%$ & 36255.3 & 44834.3 & 34688.6 & 28408.3 \\
\hline \multirow{3}{*}{$\begin{array}{r}\text { Germany } 84 / 85 \\
\text { German Marks }\end{array}$} & $<40 \%$ & 8437.8 & 10202.0 & 8044.4 & 6708.6 \\
\hline & $<50 \%$ & 10547.3 & 12752.5 & 10055.5 & 8385.8 \\
\hline & $<60 \%$ & 12656.8 & 15303.0 & 12066.5 & 10063.0 \\
\hline \multirow[t]{3}{*}{ Ireland 87} & $<40 \%$ & 1878.6 & 2482.6 & 1765.2 & 1369.4 \\
\hline & $<50 \%$ & 2348.3 & 3103.2 & 2206.5 & 1711.7 \\
\hline & $<60 \%$ & 2818.0 & 3723.8 & 2647.8 & 2054.0 \\
\hline \multirow{3}{*}{$\begin{array}{l}\text { Italy } 86 \\
\quad \text { Thousand Italian Lira }\end{array}$} & $<40 \%$ & 4292.0 & 5261.0 & 4068.0 & 3255.7 \\
\hline & $<50 \%$ & 5365.0 & 6576.3 & 5085.0 & 4069.6 \\
\hline & $<60 \%$ & 6437.9 & 7891.6 & 6102.0 & 4883.5 \\
\hline \multirow{3}{*}{$\begin{array}{l}\text { Luxembourg } 85 \\
\text { Luxembourg Francs }\end{array}$} & $<40 \%$ & 185250.0 & 231785.4 & 178027.2 & 144000.0 \\
\hline & $<50 \%$ & 231562.5 & 289731.7 & 222534.1 & 180000.0 \\
\hline & $<60 \%$ & 277874.9 & 347678.0 & 267040.9 & 216000.0 \\
\hline \multirow{3}{*}{$\begin{array}{l}\text { Netherlands } 87 \\
\text { Dutch Guilder }\end{array}$} & $<40 \%$ & 7484.8 & 8773.8 & 6904.8 & 5652.8 \\
\hline & $<50 \%$ & 9356.0 & 10967.2 & 8631.0 & 7066.1 \\
\hline & $<60 \%$ & 11227.2 & 13160.6 & 10357.2 & 8479.3 \\
\hline \multirow{3}{*}{$\begin{array}{l}\text { Sweden } 87 \\
\text { Swedish Kroner }\end{array}$} & $<40 \%$ & 29760.0 & 35640.0 & 29294.0 & 24935.6 \\
\hline & $<50 \%$ & 37200.0 & 44550.0 & 36617.5 & 31169.6 \\
\hline & $<60 \%$ & 44640.0 & 53460.0 & 43941.0 & 37403.5 \\
\hline \multirow{3}{*}{$\begin{array}{r}\text { United Kingdom } 86 \\
\text { British Pounds }\end{array}$} & $<40 \%$ & 2117.6 & 2448.7 & 1910.8 & 1559.5 \\
\hline & $<50 \%$ & 2647.1 & 3060.9 & 2388.5 & 1949.4 \\
\hline & $<60 \%$ & 3176.5 & 3673.1 & 2866.2 & 2339.2 \\
\hline \multirow{3}{*}{$\begin{array}{l}\text { United States } 86 \\
\qquad \text { US Dollars }\end{array}$} & $<40 \%$ & 5357.8 & 6515.0 & 5081.3 & 4143.6 \\
\hline & $<50 \%$ & 6697.3 & 8143.7 & 6351.6 & 5179.5 \\
\hline & $<60 \%$ & 8036.7 & 9772.4 & 7621.9 & 6215.3 \\
\hline
\end{tabular}

Sources: LIS micro data base.

Notes: $\quad<40 \%,<50 \%$, and $<60 \%$ refers to below $40 \%, 50 \%$, and $60 \%$ of median disposable income, respectively. EQ1 refers to an equivalence scale with elasticity $=0.33$ (survey-based scale), EQ2 to elasticity $=0.55$ ('policy-based' scale) and EQ3 to elasticity $=0.73$ (OECD Social Indicators scale). 


\section{B. Questions of data quality}

101. Any research using the LIS data base is restricted to the analysis of money income. Although some data files are actually based on family budget surveys (Italy, United Kingdom), information on consumption expenditures of households are not included in the LIS data bank. Also, the complex issue of imputing money values for income in kind cannot be tackled sufficiently with the available data (e.g. education, health care, housing, and food produced for own consumption) ${ }^{14}$.

102. Other data limitations are inherent in the sample design of the basic surveys. First, there is a difference in the population coverage across countries. The institutionalised population as well as the homeless are excluded from all surveys except those for Germany and the Netherlands. Moreover, there is the question whether the inclusion or exclusion of migrants in the surveys has important consequences for the representativeness of the data. In general, most of the European and all non-European surveys try to include all households, including illegal immigrants - sometimes through oversampling. However, some European countries (Germany, Italy, the Netherlands) only cover the national civilian population. This may cause some bias in the results for the low-income population.

103. The results for Austria have to be treated with special care as this is the only country which excludes entrepreneurs, and hence entrepreneurial income, from its survey (more precisely: entrepreneurs, if they are head of the household). Sensitivity test for other countries excluding this population show that this does not introduce serious bias for overall estimates of low income and poverty based on disposable income: low-income rates at the 40\%,50\% and 60\% levels, using the 'policy-based' equivalence scale, differ by only 2 to 5 percent (upwards or downwards), except for the Netherlands and Sweden where the difference was about 10 to 20 percent (downwards).

104. Another common problem of the surveys is that of non-response. Wolf (1988) has shown, that these are highest among the sub-populations at the bottom and at the top of the distribution. Hackauf et al. (1991) show for the German Transfer survey that income non-response rates are $6 \%$ and $11 \%$ for the unemployed and self-employed, respectively, with an average non-response rate of $4.7 \%$.

105. A particular problem encountered during the computations was the coding of missing values and non-responses in the income variables. Both are coded 0 , as well as 'real' zero income (which is possible in the case of specific transfers). If this does not lead to serious bias in the case of aggregates for disposable and gross income, there are problems for estimates of distribution (Gini coefficients, and low-income gaps) for the very poor population. It was therefore decided to exclude all missing values for computations of the Gini coefficient. This solution has also been adopted by Saunders (1989) who came across the same problem in the German Transferumfrage.

106. Another important issue is that of the unit definition: it is not possible for all country files to distinguish between households and families. The data for Italy and the Netherlands are available only on a household basis. The Swedish definition is that of combined tax/administrative units. A specific problem relates to young units: Young adults, economically independent but still living with their parents in a household, are counted as separate families; the share of the youth population and, ceteris paribus, the level of poverty may therefore be overestimated when using a family definition. For all other country files, data were available on a standardised family basis.

14. For a discussion of the findings from a six-year project on this topic, see Smeeding et al. 1993. 


\section{ANNEX 2: THE ANALYTICAL BACKGROUND TO THE SEN INDEX}

107. The derivation of the Sen index is based on a specific set of axioms. This foundation is independent of the particular poverty line chosen (relative or absolute) and whether the reference income measure is adjusted for size or other factors. Two axioms provide the basis for Sen's development of a synthetic poverty measure (Sen 1976): the monotonicity axiom which requires that, ceteris paribus, any poverty measure must increase if there is a reduction in income of a person below the poverty line; and the transfer axiom which requires that, ceteris paribus, a pure income transfer from a person below the poverty line to anyone richer must increase the poverty measure. The classical head-count ratio $(\mathrm{H})^{15}$ clearly violates both axioms. The income-gap ratio (I) ${ }^{16}$ satisfies the monotonicity but violates the transfer axiom. Sen (1976: 223) thus concludes that both H and I "should have some role in the index of poverty. But $H$ and I together are not sufficiently informative either, since neither gives adequate information on the exact income distribution among the poor."

108. In order to derive Sen's synthetic poverty index, a set of other axioms is necessary. The idea that an increase in incomes of a poorer person should be weighted more than that of a person relatively better off is summarised in the axiom of ordinal rank weights (axiom R) which requires that the weight on the income gap of person $i$ equals the rank order of $i$ in the interpersonal welfare ordering of the poor ${ }^{17}$. The monotonic welfare axiom (axiom $\mathrm{M}$ ) assumes a monotonic relation between welfare and income; this means that only income is assumed to determine well-being and, hence, poverty. Finally, the axiom of the normalised poverty value (axiom $\mathrm{N}$ ) states that, if all the poor have the same income, then $\mathrm{P}=\mathrm{HI}$.

109. Sen (1976: 223 ff.) shows that the only poverty index satisfying the monotonicity and the transfer axioms as well as axioms $\mathrm{R}, \mathrm{M}$ and $\mathrm{N}$ is given by:

$$
\begin{aligned}
& P=H\left[1-(1-I)\left\{1-G_{p} \frac{q}{q+1}\right\}\right] \\
& \text { where } q=\text { number of poor } \\
& \qquad \begin{array}{l}
H=\text { head-count ratio of poverty, } \frac{q}{n} \\
I=\text { income-gap ratio } \\
G_{p}=\text { Gini coefficient of the income distribution of the poor. }
\end{array}
\end{aligned}
$$

\footnotetext{
15. LIR in chapters IV and V.

16. ALG in chapters IV and V.

17. The method of constructing weights on the basis of rank orderings stems from the voting theory.
} 
For large $q$, this equation converges to:

$$
P=H\left[I+(1-I) G_{p}\right]
$$

110. This formula has been used for the poverty estimates presented in chapters IV and V. As for the interpretation of the Sen index, several points are noteworthy. First, it can be seen that the income-gap ratio is augmented to take into account inequality among the poor, i.e., $\left[I+(1-I) G_{p}\right]$ is normalised per poor person, and does not take note of the number of people below the poverty line. Multiplying [I + (1 - I $)$ $\mathrm{G}_{\mathrm{p}}$ ] by $\mathrm{H}$ then produces the synthetic poverty measure proposed by Sen. Second, Sen's approach is based on ordinal level comparability of welfare rather than on interpersonal comparable cardinal welfare functions. It should also be noted that the Sen index depends a priori only on the incomes of the poor and is insensitive to changes in incomes of persons above the poverty line, unless a relative poverty line is chosen.

111. Starting from Sen's contribution, many alternative poverty measures (known as $\mathrm{P}_{\alpha}$-class measure ${ }^{18}$ ) have been developed and applied in the past two decades. A recent contribution (Bourguignon/Fields 1990) uses such measures of poverty (including the Sen index) to test assumptions about the optimal allocation of an anti-poverty budget. It should be noted, however, that any choice for a poverty index includes an element of value judgement, namely about the social welfare function (cf. Stiglitz 1988: 102ff).

18. One of the best-known Pa poverty measures is the Foster Index (Foster et al. 1984) which is defined as:

$$
\begin{aligned}
& F_{\alpha}=-\frac{\left(z-y_{i}\right)^{\alpha}}{z^{\alpha}}, \text { for } \alpha>0 \\
& \text { where } \quad \begin{aligned}
q & =\text { number of persons having incomes below } z \\
z & =\text { low-income threshold } \\
y_{i} & =\text { income of the } \mathrm{i}^{\text {th }} \text { individual of the low-income population } \\
n & =\text { population } \\
\alpha & =\text { Foster coefficient. }
\end{aligned}
\end{aligned}
$$


ANNEX 3: STATISTICAL TABLES FOR COMPONENTS OF THE SEN INDEX

Table A.3: Sen poverty index and its components before and after taxes and transfers, for all non-elderly families

\begin{tabular}{|c|c|c|c|c|c|c|c|c|c|c|}
\hline & & \multicolumn{4}{|c|}{$\begin{array}{c}\text { BEFORE TAXES AND } \\
\text { TRANSFERS } \\
\end{array}$} & \multicolumn{4}{|c|}{$\begin{array}{c}\text { AFTER TAXES AND } \\
\text { TRANSFERS } \\
\end{array}$} & \multirow{2}{*}{$\begin{array}{c}\text { REDUCTION } \\
\text { IN SEN } \\
\text { INDEX } \\
\end{array}$} \\
\hline & & LIR & ALG & $\mathrm{Gp}$ & Sen & LIR & ALG & $\mathrm{Gp}$ & Sen & \\
\hline \multirow[t]{3}{*}{ Australia $85 / 86$} & $<40 \%$ & 15.3 & 60.7 & 0.4542 & 12.02 & 8.9 & 33.5 & 0.2373 & 4.38 & $63.5 \%$ \\
\hline & $<50 \%$ & 17.6 & 57.0 & 0.4361 & 13.33 & 15.7 & 30.7 & 0.1952 & 6.94 & $47.9 \%$ \\
\hline & $<60 \%$ & 20.5 & 52.5 & 0.4027 & 14.69 & 21.3 & 33.4 & 0.1934 & 9.86 & $32.9 \%$ \\
\hline \multirow[t]{3}{*}{ Belgium 85} & $<40 \%$ & 16.0 & 34.0 & 0.2216 & 7.78 & 2.3 & 34.6 & 0.2385 & 1.15 & $85.2 \%$ \\
\hline & $<50 \%$ & 22.7 & 26.6 & 0.1619 & 8.74 & 5.4 & 25.0 & 0.1748 & 2.06 & $76.4 \%$ \\
\hline & $<60 \%$ & 29.9 & 24.0 & 0.1383 & 10.31 & 11.6 & 21.3 & 0.1311 & 3.67 & $64.5 \%$ \\
\hline \multirow[t]{3}{*}{ Canada 87} & $<40 \%$ & 15.8 & 47.2 & 0.3221 & 10.14 & 10.5 & 30.5 & 0.1885 & 4.58 & $54.8 \%$ \\
\hline & $<50 \%$ & 19.0 & 46.5 & 0.3141 & 12.03 & 15.4 & 33.2 & 0.1890 & 7.05 & $41.4 \%$ \\
\hline & $<60 \%$ & 22.7 & 46.4 & 0.3098 & 14.31 & 21.1 & 34.4 & 0.1989 & 10.01 & $30.1 \%$ \\
\hline \multirow[t]{3}{*}{ France 84} & $<40 \%$ & 14.5 & 39.6 & 0.2689 & 8.10 & 5.2 & 37.9 & 0.2343 & 2.73 & $66.3 \%$ \\
\hline & $<50 \%$ & 20.6 & 37.1 & 0.2466 & 10.84 & 8.9 & 33.3 & 0.2185 & 4.26 & $60.7 \%$ \\
\hline & $<60 \%$ & 27.2 & 36.6 & 0.2333 & 13.99 & 15.0 & 29.6 & 0.1925 & 6.47 & $53.7 \%$ \\
\hline \multirow[t]{3}{*}{ Germany $84 / 85$} & $<40 \%$ & 10.7 & 64.7 & 0.5199 & 8.89 & 3.8 & 23.5 & 0.1431 & 1.31 & $85.3 \%$ \\
\hline & $<50 \%$ & 12.4 & 59.5 & 0.4837 & 9.80 & 8.5 & 23.2 & 0.1340 & 2.84 & $71.0 \%$ \\
\hline & $<60 \%$ & 14.6 & 54.6 & 0.4394 & 10.88 & 14.5 & 24.2 & 0.1379 & 5.02 & $53.9 \%$ \\
\hline \multirow[t]{3}{*}{ Ireland 87} & $<40 \%$ & 23.6 & 59.1 & 0.4468 & 18.26 & 5.5 & 42.2 & 0.2959 & 3.26 & $82.1 \%$ \\
\hline & $<50 \%$ & 26.3 & 57.1 & 0.4227 & 19.79 & 15.7 & 24.9 & 0.1730 & 5.94 & $70.0 \%$ \\
\hline & $<60 \%$ & 29.9 & 53.7 & 0.3988 & 21.57 & 23.4 & 27.4 & 0.1567 & 9.08 & $57.9 \%$ \\
\hline \multirow[t]{3}{*}{ Netherlands 87} & $<40 \%$ & 18.1 & 45.9 & 0.2897 & 11.14 & 2.4 & 33.2 & 0.2546 & 1.20 & $89.2 \%$ \\
\hline & $<50 \%$ & 18.9 & 45.8 & 0.2965 & 11.70 & 4.7 & 28.8 & 0.1971 & 2.01 & $82.8 \%$ \\
\hline & $<60 \%$ & 19.7 & 45.6 & 0.2918 & 12.11 & 11.3 & 20.9 & 0.1398 & 3.61 & $70.2 \%$ \\
\hline \multirow[t]{3}{*}{ Sweden 87} & $<40 \%$ & 15.5 & 54.6 & 0.3950 & 11.24 & 6.9 & 40.4 & 0.1392 & 3.36 & $70.1 \%$ \\
\hline & $<50 \%$ & 18.4 & 54.4 & 0.3865 & 13.25 & 10.6 & 41.0 & 0.1485 & 5.28 & $60.2 \%$ \\
\hline & $<60 \%$ & 22.2 & 51.9 & 0.3740 & 15.51 & 16.1 & 40.1 & 0.1527 & 7.92 & $49.0 \%$ \\
\hline \multirow[t]{3}{*}{ U K 86} & $<40 \%$ & 21.6 & 60.0 & 0.4955 & 17.24 & 5.6 & 38.3 & 0.2752 & 3.10 & $82.0 \%$ \\
\hline & $<50 \%$ & 24.0 & 57.1 & 0.4526 & 18.37 & 12.4 & 27.6 & 0.1907 & 5.13 & $72.1 \%$ \\
\hline & $<60 \%$ & 26.8 & 53.7 & 0.4188 & 19.59 & 20.6 & 26.9 & 0.1649 & 8.03 & $59.0 \%$ \\
\hline \multirow[t]{4}{*}{ U S 86} & $<40 \%$ & 16.0 & 51.2 & 0.3659 & 11.05 & 13.9 & 37.0 & 0.2249 & 7.12 & $35.6 \%$ \\
\hline & $<50 \%$ & 19.4 & 49.3 & 0.3484 & 12.99 & 18.7 & 39.5 & 0.2326 & 10.02 & $22.8 \%$ \\
\hline & $<60 \%$ & 23.1 & 47.9 & 0.3353 & 15.10 & 24.4 & 39.8 & 0.2394 & 13.24 & $12.3 \%$ \\
\hline & $<40 \%$ & 16.7 & 51.7 & 0.3780 & 11.59 & 6.5 & 35.1 & 0.2232 & 3.22 & $71.4 \%$ \\
\hline \multirow[t]{2}{*}{ Average } & $<50 \%$ & 19.9 & 49.0 & 0.3549 & 13.08 & 11.6 & 30.7 & 0.1853 & 5.15 & $60.5 \%$ \\
\hline & $<60 \%$ & 23.7 & 46.7 & 0.3342 & 14.81 & 17.9 & 29.8 & 0.1707 & 7.69 & $48.3 \%$ \\
\hline
\end{tabular}

Source: LIS micro data base.

Notes: $\quad$ Income adjusted for family size (equivalence elasticity $=0.55$ ). LIR =low-income rate. ALG $=$ low-income gap. $\mathrm{G}_{\mathrm{p}}=$ Gini (poor). Sen = Sen poverty index *100. Further definitions and methods, see chapter IV. 
Table A.4: Sen poverty index and its components before and after taxes and transfers, for non-elderly families with three or more children

\begin{tabular}{|c|c|c|c|c|c|c|c|c|c|c|}
\hline & & \multicolumn{4}{|c|}{$\begin{array}{c}\text { BEFORE TAXES AND } \\
\text { TRANSFERS } \\
\end{array}$} & \multicolumn{4}{|c|}{$\begin{array}{c}\text { AFTER TAXES AND } \\
\text { TRANSFERS } \\
\end{array}$} & \multirow{2}{*}{$\begin{array}{l}\text { REDUCTION } \\
\text { IN SEN } \\
\text { INDEX }\end{array}$} \\
\hline & & LIR & ALG & $\mathrm{Gp}$ & Sen & LIR & ALG & $\mathrm{Gp}$ & Sen & \\
\hline \multirow[t]{3}{*}{ Australia 85/86 } & $<40 \%$ & 20.6 & 49.3 & 0.3603 & 13.92 & 14.2 & 35.3 & 0.2389 & 7.21 & $48.2 \%$ \\
\hline & $<50 \%$ & 24.4 & 47.8 & 0.3372 & 15.95 & 24.5 & 32.1 & 0.2061 & 11.29 & $29.2 \%$ \\
\hline & $<60 \%$ & 31.3 & 41.0 & 0.2953 & 18.28 & 36.7 & 31.9 & 0.1939 & 16.55 & $9.5 \%$ \\
\hline \multirow[t]{3}{*}{ Belgium 85} & $<40 \%$ & 23.2 & 20.6 & 0.1258 & 7.10 & 2.8 & 24.9 & 0.1423 & 1.00 & $86.0 \%$ \\
\hline & $<50 \%$ & 38.5 & 21.2 & 0.1154 & 11.65 & 7.3 & 20.7 & 0.1292 & 2.26 & $80.6 \%$ \\
\hline & $<60 \%$ & 52.6 & 25.2 & 0.1202 & 17.99 & 20.5 & 17.1 & 0.0983 & 5.17 & $71.3 \%$ \\
\hline \multirow[t]{3}{*}{ Canada 87} & $<40 \%$ & 21.2 & 45.8 & 0.3208 & 13.40 & 13.7 & 22.8 & 0.1369 & 4.57 & $65.9 \%$ \\
\hline & $<50 \%$ & 27.7 & 42.8 & 0.3013 & 16.63 & 23.0 & 26.3 & 0.1435 & 8.48 & $49.0 \%$ \\
\hline & $<60 \%$ & 32.3 & 44.9 & 0.2939 & 19.72 & 33.6 & 28.4 & 0.1566 & 13.32 & $32.5 \%$ \\
\hline \multirow[t]{3}{*}{ France 84} & $<40 \%$ & 34.4 & 35.0 & 0.2396 & 17.41 & 4.6 & 23.8 & 0.1580 & 1.65 & $90.5 \%$ \\
\hline & $<50 \%$ & 47.6 & 36.1 & 0.2257 & 24.06 & 10.5 & 21.0 & 0.1519 & 3.46 & $85.6 \%$ \\
\hline & $<60 \%$ & 58.3 & 39.4 & 0.2282 & 31.03 & 22.6 & 20.9 & 0.1270 & 6.99 & $77.5 \%$ \\
\hline \multirow[t]{3}{*}{ Germany $84 / 85$} & $<40 \%$ & 11.7 & 51.3 & 0.3437 & 7.96 & 5.3 & 25.5 & 0.1964 & 2.13 & $73.3 \%$ \\
\hline & $<50 \%$ & 14.5 & 48.6 & 0.3445 & 9.61 & 12.7 & 22.4 & 0.1496 & 4.32 & $55.1 \%$ \\
\hline & $<60 \%$ & 23.8 & 34.0 & 0.3155 & 13.04 & 22.9 & 23.7 & 0.1451 & 7.96 & $39.0 \%$ \\
\hline \multirow[t]{3}{*}{ Ireland 87} & $<40 \%$ & 28.2 & 60.2 & 0.4361 & 21.86 & 5.8 & 41.6 & 0.2125 & 3.13 & $85.7 \%$ \\
\hline & $<50 \%$ & 31.5 & 58.1 & 0.4150 & 23.78 & 21.9 & 20.7 & 0.1273 & 6.74 & $71.7 \%$ \\
\hline & $<60 \%$ & 36.5 & 53.5 & 0.3914 & 26.18 & 31.9 & 25.2 & 0.1270 & 11.06 & $57.7 \%$ \\
\hline \multirow[t]{3}{*}{ Netherlands 87} & $<40 \%$ & 13.6 & 45.5 & 0.3473 & 8.76 & 6.3 & 20.9 & 0.2096 & 2.36 & $73.0 \%$ \\
\hline & $<50 \%$ & 13.8 & 56.4 & 0.3473 & 9.87 & 11.0 & 23.9 & 0.1742 & 4.09 & $58.6 \%$ \\
\hline & $<60 \%$ & 26.1 & 42.5 & 0.3089 & 15.73 & 29.3 & 18.5 & 0.1276 & 8.46 & $46.2 \%$ \\
\hline \multirow[t]{3}{*}{ Sweden 87} & $<40 \%$ & 12.6 & 52.8 & 0.3575 & 8.78 & 1.9 & 26.2 & 0.1120 & 0.65 & $92.5 \%$ \\
\hline & $<50 \%$ & 17.5 & 47.2 & 0.3314 & 11.32 & 3.7 & 24.9 & 0.1089 & 1.22 & $89.2 \%$ \\
\hline & $<60 \%$ & 22.7 & 44.4 & 0.3048 & 13.92 & 7.9 & 20.2 & 0.0986 & 2.22 & $84.1 \%$ \\
\hline \multirow[t]{3}{*}{ U K 86} & $<40 \%$ & 37.8 & 50.0 & 0.3942 & 26.36 & 8.8 & 33.5 & 0.2514 & 4.42 & $83.2 \%$ \\
\hline & $<50 \%$ & 41.0 & 51.2 & 0.3704 & 28.40 & 24.7 & 22.7 & 0.1524 & 8.52 & $70.0 \%$ \\
\hline & $<60 \%$ & 46.1 & 48.5 & 0.3560 & 30.82 & 38.8 & 26.0 & 0.1378 & 14.06 & $54.4 \%$ \\
\hline \multirow[t]{3}{*}{ U S 86} & $<40 \%$ & 30.0 & 51.8 & 0.3601 & 20.74 & 28.1 & 34.1 & 0.1896 & 13.10 & $36.8 \%$ \\
\hline & $<50 \%$ & 35.0 & 51.4 & 0.3531 & 24.00 & 37.1 & 38.4 & 0.2107 & 19.06 & $20.6 \%$ \\
\hline & $<60 \%$ & 41.3 & 49.1 & 0.3444 & 27.53 & 44.5 & 41.6 & 0.2278 & 24.45 & $11.2 \%$ \\
\hline \multirow{3}{*}{ Average } & $<40 \%$ & 23.3 & 46.2 & 0.3285 & 14.63 & 9.2 & 28.9 & 0.1848 & 4.02 & $73.5 \%$ \\
\hline & $<50 \%$ & 29.2 & 46.1 & 0.3141 & 17.53 & 17.6 & 25.3 & 0.1554 & 6.94 & $61.0 \%$ \\
\hline & $<60 \%$ & 37.1 & 42.3 & 0.2959 & 21.43 & 28.9 & 25.3 & 0.1440 & 11.02 & $48.3 \%$ \\
\hline
\end{tabular}

Source: LIS micro data base.

Notes: $\quad$ Income adjusted for family size (equivalence elasticity $=0.55$ ). LIR $=$ low-income rate. ALG $=$ low-income gap. $G_{p}=$ Gini (poor). Sen = Sen poverty index $* 100$. Further definitions and methods, see chapter IV. 
Table A.5: Sen poverty index and its components before and after taxes and transfers, for non-elderly single parent families

\begin{tabular}{|c|c|c|c|c|c|c|c|c|c|c|}
\hline & \multicolumn{4}{|c|}{$\begin{array}{l}\text { BEFORE TAXES AND } \\
\text { TRANSFERS }\end{array}$} & \multicolumn{4}{|c|}{$\begin{array}{c}\text { AFTER TAXES AND } \\
\text { TRANSFERS }\end{array}$} & \multirow{2}{*}{$\begin{array}{c}\text { REDUCTION } \\
\text { IN SEN } \\
\text { INDEX }\end{array}$} \\
\hline & & LIR & ALG & $\mathrm{Gp}$ & Sen & LIR & ALG & $\mathrm{Gp}$ & Sen & \\
\hline \multirow[t]{3}{*}{ Australia 85/86 } & $<40 \%$ & 59.3 & 73.0 & 0.5275 & 51.73 & 39.5 & 27.6 & 0.1679 & 15.70 & $69.6 \%$ \\
\hline & $<50 \%$ & 62.5 & 69.4 & 0.5372 & 53.65 & 55.6 & 33.2 & 0.1690 & 24.74 & $53.9 \%$ \\
\hline & $<60 \%$ & 65.5 & 67.2 & 0.5280 & 55.36 & 62.5 & 40.4 & 0.1840 & 32.10 & $42.0 \%$ \\
\hline \multirow[t]{3}{*}{ Belgium 85} & $<40 \%$ & 51.1 & 31.1 & 0.2121 & 23.35 & 9.4 & 36.5 & 0.2764 & 5.08 & $78.2 \%$ \\
\hline & $<50 \%$ & 63.3 & 29.3 & 0.1924 & 27.16 & 19.4 & 27.6 & 0.1886 & 8.00 & $70.5 \%$ \\
\hline & $<60 \%$ & 68.3 & 33.3 & 0.1816 & 31.01 & 34.5 & 25.1 & 0.1573 & 12.73 & $58.9 \%$ \\
\hline \multirow[t]{3}{*}{ Canada 87} & $<40 \%$ & 53.0 & 58.3 & 0.4097 & 39.95 & 36.6 & 25.1 & 0.1532 & 13.39 & $66.5 \%$ \\
\hline & $<50 \%$ & 57.1 & 59.9 & 0.4122 & 43.64 & 48.6 & 32.1 & 0.1638 & 21.01 & $51.9 \%$ \\
\hline & $<60 \%$ & 62.8 & 58.4 & 0.4164 & 47.55 & 57.6 & 38.1 & 0.1813 & 28.41 & $40.3 \%$ \\
\hline \multirow[t]{3}{*}{ France 84} & $<40 \%$ & 36.1 & 45.6 & 0.3595 & 23.52 & 11.8 & 30.9 & 0.1986 & 5.27 & $77.6 \%$ \\
\hline & $<50 \%$ & 44.4 & 44.6 & 0.3269 & 27.84 & 18.6 & 32.2 & 0.1970 & 8.47 & $69.6 \%$ \\
\hline & $<60 \%$ & 60.4 & 39.7 & 0.2803 & 34.19 & 31.0 & 29.4 & 0.1959 & 13.40 & $60.8 \%$ \\
\hline \multirow[t]{3}{*}{ Germany $84 / 85$} & $<40 \%$ & 40.0 & 69.6 & 0.4972 & 33.89 & 16.4 & 29.1 & 0.1804 & 6.87 & $79.7 \%$ \\
\hline & $<50 \%$ & 46.5 & 56.8 & 0.5314 & 37.09 & 33.3 & 25.1 & 0.1785 & 12.81 & $65.5 \%$ \\
\hline & $<60 \%$ & 50.0 & 56.9 & 0.4890 & 38.99 & 46.0 & 29.4 & 0.1768 & 19.27 & $50.6 \%$ \\
\hline \multirow[t]{3}{*}{ Ireland 87} & $<40 \%$ & 48.6 & 66.0 & 0.3467 & 37.80 & 14.8 & 43.2 & 0.2138 & 8.19 & $78.3 \%$ \\
\hline & $<50 \%$ & 56.6 & 51.6 & 0.3240 & 38.08 & 32.6 & 29.5 & 0.1832 & 13.83 & $63.7 \%$ \\
\hline & $<60 \%$ & 62.1 & 49.4 & 0.3087 & 40.38 & 43.5 & 32.9 & 0.1675 & 19.20 & $52.4 \%$ \\
\hline \multirow[t]{3}{*}{ Netherlands 87} & $<40 \%$ & 70.2 & 48.7 & 0.3800 & 47.87 & 7.3 & 40.4 & 0.3832 & 4.62 & $90.4 \%$ \\
\hline & $<50 \%$ & 73.9 & 41.7 & 0.3169 & 44.47 & 12.0 & 33.7 & 0.3201 & 6.59 & $85.2 \%$ \\
\hline & $<60 \%$ & 75.3 & 46.3 & 0.3093 & 47.37 & 33.7 & 19.5 & 0.1604 & 10.92 & $76.9 \%$ \\
\hline \multirow[t]{3}{*}{ Sweden 87} & $<40 \%$ & 31.6 & 87.1 & 0.4348 & 29.30 & 3.8 & 17.4 & 0.1061 & 0.99 & $96.6 \%$ \\
\hline & $<50 \%$ & 38.3 & 55.4 & 0.4108 & 28.24 & 5.9 & 25.6 & 0.1102 & 1.99 & $92.9 \%$ \\
\hline & $<60 \%$ & 46.4 & 52.4 & 0.3998 & 33.14 & 13.7 & 20.1 & 0.1167 & 4.03 & $87.8 \%$ \\
\hline \multirow[t]{3}{*}{ U K 86} & $<40 \%$ & 70.5 & 64.8 & 0.5438 & 59.18 & 10.2 & 30.0 & 0.1999 & 4.49 & $92.4 \%$ \\
\hline & $<50 \%$ & 75.1 & 62.4 & 0.5065 & 61.16 & 28.3 & 21.4 & 0.1319 & 8.99 & $85.3 \%$ \\
\hline & $<60 \%$ & 77.7 & 63.7 & 0.4950 & 63.46 & 53.5 & 21.8 & 0.1204 & 16.70 & $73.7 \%$ \\
\hline \multirow[t]{3}{*}{ U S 86} & $<40 \%$ & 50.5 & 60.2 & 0.4382 & 39.21 & 44.8 & 36.3 & 0.1971 & 21.89 & $44.2 \%$ \\
\hline & $<50 \%$ & 57.5 & 56.3 & 0.4201 & 42.93 & 54.8 & 41.8 & 0.2197 & 29.91 & $30.3 \%$ \\
\hline & $<60 \%$ & 62.9 & 56.7 & 0.4105 & 46.84 & 61.2 & 47.1 & 0.2382 & 36.54 & $22.0 \%$ \\
\hline \multirow{3}{*}{ Average } & $<40 \%$ & 51.1 & 60.4 & 0.4150 & 38.58 & 19.5 & 31.6 & 0.2077 & 8.65 & $77.4 \%$ \\
\hline & $<50 \%$ & 57.5 & 52.7 & 0.3978 & 40.43 & 30.9 & 30.2 & 0.1862 & 13.63 & $66.9 \%$ \\
\hline & $<60 \%$ & 63.1 & 52.4 & 0.3819 & 43.83 & 43.7 & 30.4 & 0.1699 & 19.33 & $56.6 \%$ \\
\hline
\end{tabular}

Source: LIS micro data base.

Notes: $\quad$ Income adjusted for family size (equivalence elasticity $=0.55$ ). LIR =low-income rate. ALG $=$ low-income gap. $\mathrm{G}_{\mathrm{p}}=$ Gini (poor). Sen $=$ Sen poverty index $* 100$. Further definitions and methods, see chapter IV. 
Table A.6: Sen poverty index and its components before and after taxes and transfers, for children

\begin{tabular}{|c|c|c|c|c|c|c|c|c|c|c|}
\hline & & \multicolumn{4}{|c|}{$\begin{array}{c}\text { BEFORE TAXES AND } \\
\text { TRANSFERS } \\
\end{array}$} & \multicolumn{4}{|c|}{$\begin{array}{c}\text { AFTER TAXES AND } \\
\text { TRANSFERS } \\
\end{array}$} & \multirow{2}{*}{\begin{tabular}{|c} 
REDUCTION \\
IN SEN \\
INDEX
\end{tabular}} \\
\hline & & LIR & ALG & $\mathrm{Gp}$ & Sen & LIR & ALG & $\mathrm{Gp}$ & Sen & \\
\hline \multirow[t]{3}{*}{ Australia 85/86 } & $<40 \%$ & 15.7 & 58.9 & 0.4464 & 12.12 & 7.1 & 41.0 & 0.2932 & 4.14 & $65.9 \%$ \\
\hline & $<50 \%$ & 17.5 & 56.6 & 0.4275 & 13.15 & 12.0 & 33.7 & 0.2369 & 5.93 & $54.9 \%$ \\
\hline & $<60 \%$ & 19.7 & 53.2 & 0.4047 & 14.22 & 18.2 & 32.5 & 0.2084 & 8.48 & $40.4 \%$ \\
\hline \multirow[t]{3}{*}{ Belgium 85} & $<40 \%$ & 13.7 & 33.0 & 0.2082 & 6.43 & 1.7 & 29.4 & 0.1999 & 0.74 & $88.5 \%$ \\
\hline & $<50 \%$ & 21.8 & 25.9 & 0.1731 & 8.44 & 3.6 & 24.4 & 0.1671 & 1.33 & $84.2 \%$ \\
\hline & $<60 \%$ & 33.1 & 25.0 & 0.1476 & 11.93 & 9.7 & 17.8 & 0.1325 & 2.78 & $76.7 \%$ \\
\hline \multirow[t]{3}{*}{ Canada 87} & $<40 \%$ & 14.9 & 48.5 & 0.3459 & 9.88 & 7.1 & 25.5 & 0.1874 & 2.80 & $71.7 \%$ \\
\hline & $<50 \%$ & 18.4 & 46.1 & 0.3273 & 11.73 & 12.6 & 27.3 & 0.1579 & 4.89 & $58.3 \%$ \\
\hline & $<60 \%$ & 22.5 & 44.8 & 0.3111 & 13.95 & 18.5 & 28.8 & 0.1627 & 7.48 & $46.4 \%$ \\
\hline \multirow[t]{3}{*}{ France 84} & $<40 \%$ & 17.5 & 36.2 & 0.2707 & 9.36 & 3.3 & 31.1 & 0.2106 & 1.51 & $83.9 \%$ \\
\hline & $<50 \%$ & 24.7 & 36.1 & 0.2387 & 12.68 & 5.7 & 28.9 & 0.1855 & 2.40 & $81.1 \%$ \\
\hline & $<60 \%$ & 33.6 & 35.3 & 0.2251 & 16.74 & 11.5 & 23.8 & 0.1613 & 4.15 & $75.2 \%$ \\
\hline \multirow[t]{3}{*}{ Germany $84 / 85$} & $<40 \%$ & 8.4 & 54.3 & 0.4091 & 6.13 & 1.7 & 25.4 & 0.1806 & 0.66 & $89.2 \%$ \\
\hline & $<50 \%$ & 9.7 & 51.7 & 0.3987 & 6.88 & 3.8 & 23.4 & 0.1523 & 1.33 & $80.7 \%$ \\
\hline & $<60 \%$ & 11.3 & 50.2 & 0.3769 & 7.79 & 8.8 & 19.7 & 0.1266 & 2.63 & $66.3 \%$ \\
\hline \multirow[t]{3}{*}{ Ireland 87} & $<40 \%$ & 26.6 & 59.3 & 0.4886 & 21.06 & 4.5 & 48.7 & 0.3255 & 2.94 & $86.0 \%$ \\
\hline & $<50 \%$ & 29.3 & 57.7 & 0.4455 & 22.43 & 7.6 & 38.9 & 0.2931 & 4.32 & $80.8 \%$ \\
\hline & $<60 \%$ & 32.4 & 57.0 & 0.4259 & 24.41 & 21.8 & 22.2 & 0.1550 & 7.48 & $69.4 \%$ \\
\hline \multirow[t]{3}{*}{ Netherlands 87} & $<40 \%$ & 13.5 & 46.3 & 0.3691 & 8.92 & 1.8 & 39.2 & 0.3285 & 1.07 & $88.1 \%$ \\
\hline & $<50 \%$ & 14.3 & 46.0 & 0.3289 & 9.12 & 4.1 & 26.1 & 0.2361 & 1.79 & $80.4 \%$ \\
\hline & $<60 \%$ & 14.9 & 48.0 & 0.3243 & 9.66 & 6.1 & 27.9 & 0.1989 & 2.58 & $73.3 \%$ \\
\hline \multirow[t]{3}{*}{ Sweden 87} & $<40 \%$ & 9.9 & 53.1 & 0.3977 & 7.10 & 2.0 & 24.0 & 0.1475 & 0.70 & $90.1 \%$ \\
\hline & $<50 \%$ & 13.1 & 48.6 & 0.3638 & 8.81 & 3.7 & 24.6 & 0.1327 & 1.28 & $85.5 \%$ \\
\hline & $<60 \%$ & 17.0 & 44.9 & 0.3294 & 10.72 & 7.1 & 22.7 & 0.1327 & 2.34 & $78.1 \%$ \\
\hline \multirow[t]{3}{*}{ U K 86} & $<40 \%$ & 26.5 & 58.9 & 0.4948 & 21.00 & 4.3 & 46.6 & 0.3463 & 2.80 & $86.7 \%$ \\
\hline & $<50 \%$ & 29.5 & 54.6 & 0.4398 & 22.00 & 7.3 & 37.6 & 0.2817 & 4.03 & $81.7 \%$ \\
\hline & $<60 \%$ & 32.6 & 52.0 & 0.4012 & 23.23 & 16.2 & 25.8 & 0.1877 & 6.44 & $72.3 \%$ \\
\hline \multirow[t]{4}{*}{ U S 86} & $<40 \%$ & 20.2 & 51.3 & 0.3730 & 14.03 & 14.2 & 30.2 & 0.1725 & 5.99 & $57.3 \%$ \\
\hline & $<50 \%$ & 23.3 & 51.2 & 0.3591 & 16.01 & 21.0 & 32.9 & 0.1844 & 9.50 & $40.6 \%$ \\
\hline & $<60 \%$ & 26.9 & 49.7 & 0.3484 & 18.08 & 26.4 & 36.3 & 0.1489 & 12.10 & $33.1 \%$ \\
\hline & $<40 \%$ & 16.7 & 50.0 & 0.3804 & 11.60 & 4.8 & 34.1 & 0.2392 & 2.33 & $80.7 \%$ \\
\hline \multirow[t]{2}{*}{ Average } & $<50 \%$ & 20.2 & 47.4 & 0.3502 & 13.13 & 8.1 & 29.8 & 0.2028 & 3.68 & $72.8 \%$ \\
\hline & $<60 \%$ & 24.4 & 46.0 & 0.3295 & 15.07 & 14.4 & 25.8 & 0.1615 & 5.64 & $63.1 \%$ \\
\hline
\end{tabular}

Source: LIS micro data base.

Notes: $\quad$ Income adjusted for family size (equivalence elasticity $=0.55$ ). LIR =low-income rate. ALG $=$ low-income gap. $\mathrm{G}_{\mathrm{p}}=$ Gini (poor). Sen $=$ Sen poverty index $* 100$. Further definitions and methods, see chapter IV. 


\section{REFERENCES}

ATKINSON, A.B. (1987), "Income Maintenance and Social Insurance". Handbook of Public Economics, vol.II, pp. 779-908.

ATKINSON, A.B. (1991), "Poverty, Statistics, and Progress in Europe", Discussion Paper WSP/60, The Welfare State Programme, Suntory-Toyota International, Centre for Economics and Related Disciplines, London School of Economics.

ATKINSON, A.B. (1992), "Measuring Poverty and Differences in Family Composition". Economica 59 February 1992, pp. 1-16.

BECKERMAN, W. (1978), "Estimates of Poverty in Italy in 1975", WEP 2-23/ Working Paper 70, ILO (Geneva).

BISHOP, J., FORMBY, J. and SMITH, J. (1991), "International Comparisons of Income Inequality: Tests for Lorenz Dominance Across Nine Countries". Economica 58, pp. 461-477.

BOURGIGNON, F. and FIELDS, G. (1990), "Poverty Measures and Anti-Poverty Policy". Recherches économiques de Louvain, Vol. 56 - 1990, No.3-4, pp.409-427. Université catholique de Louvain 1990.

BUHMANN, B., RAINWATER, L., SCHMAUS, G. and SMEEDING,T. (1988), "Equivalence Scales, Well-Being, Inequality, and Poverty: Sensitivity Estimates Across Ten Countries using the LIS Database". Review of Income and Wealth, 34 (June 1988), pp. 115-142.

DELEECK, H. and VAN DEN BOSCH, K. (1989), "The Measurement of Poverty in a Comparative Context: Empirical Evidence and Methodological Evaluation of Four Poverty Lines in Seven EC Countries". Paper presented at the seminar 'Poverty Statistics in the EC', Noordwijk, 1989.

DE VOS, K. and GARNER,T. (1989), "An evaluation of subjective poverty definitions comparing results from the U.S. and the Netherlands", Paper presented at the 21st General Conference on the international Association for Research in Income and Wealth. Rotterdam/Washington, 1989.

DUNCAN, G. (1984), "Years of poverty, years of plenty". Ann Arbor: Survey research center, University of Michigan.

EUROSTAT (1990), "Poverty in Figures: Europe in the Early 1980s". Study carried out by the Institute of Social Studies Advisory Service (Issas).

FOSTER, J.E., GREER, J. and THORBECKE,E. (1984), "A Class of Decomposable Poverty Measures". Econometrica, vol.48, pp.1053-1060. 
GLAUDE, M. and MOUTARDIER, M. (1989), "Estimations d'échelles d'équivalence pour la France en 1979, 1985 et 1989". INSEE, 1989.

GUSTAFSSON, B. and UUSITALO, H. (1989), "The Welfare State and Poverty in Finland and Sweden from the Mid-1960s to the Mid-1980s", Paper presented at the 21st General Conference on the international Association for Research in Income and Wealth.

HACKAUF, RANDELL, CODER, SMEEDING and WARNER (1990), "Final Report for the Statistical Office of the European Community Project on Technical Documentation and Income Data Quality for the Luxembourg Income Study Database: Phase Two". Paper presented to the Statistical Office of the EC, December 1990.

HADDAD, L. and KANBUR, R. (1990), "How Serious is the Neglect of Intra- Household Inequality?". The Economic Journal, 100 (September 1990), pp. 866-881.

HAGENAARS, A. and DE VOS, K. (1987), "The Definition and Measurement of Poverty". The Journal of Human Resources, XXIII/2, pp. 211-221.

MITCHELL, D. and BRADSHAW, J. (1991), "Lone Parents and Their Incomes: A Comparative Study of Ten Countries", ESRC Project Report. University of York 1991.

MORRIS, N. and PRESTON, I. (1986), "Inequality". Bulletin of Economic Research 38:4 (1986), pp. 279-299.

OECD (1976), "Public Expenditure on Income Maintenance Programmes". Paris 1976.

OECD (1982), "The OECD List of Social Indicators". Paris 1982.

OECD (1988), "The Future of Social Protection". Paris 1988.

OECD (1990a), "Lone-Parent Families. The Economic Challenge". Paris, 1990.

OECD (1990b), "The Personal Income Tax Base. A Comparative Survey." Paris 1990.

OECD (1994, forthcoming), "Income Distribution in OECD Countries : The Evidence From the Luxembourg Income Study". Paris, forthcoming.

ORSHANSKY, M. (1965), "Counting the Poor: Another Look at the Poverty Profile". Social Security Bulletin 28, pp. 3-29.

PIACHAUD, D. (1987), "Problems in the Definition and Measurement of Poverty". Journal of Social Policy 16.2, pp. 147-164.

QVORTRUP, J. (1990), "Childhood as a Social Phenomenon". European Centre for Social Welfare Policy and Research Report 36, Vienna 1990.

RAINWATER, L. (1988), "Inequalities in the Economic Well-Being of Children and Adults in Ten Nations". LIS Working Paper No. 19. 
RAINWATER, L. (1990), "Poverty and Equivalence as Social Constructions". LIS Working Paper No. 55.

SEN, A. (1976), "Poverty: an ordinal approach to measurement". Econometrica 44, pp. 219-231.

SEN, A. (1983), "Poor, relatively speaking". Oxford Economic Papers Vol.35, No.2 (1983), pp. 153-170.

SHORT, K. and GARNER, T. (1989), "Living Arrangements of young Adults living independently". LIS Working Paper No. 29.

SMEEDING, T. and TORREY, B. (1988), "Poor Children in Rich Countries". Science Vol. 242, pp. 873-877. The American Association for the Advancement of Science, 1988.

SMEEDING, T. (1989), "Poverty, Affluence, and the Income Costs of Children: Cross-national Evidence from the Luxembourg Income Study". Journal of Post Keynesian Economics /Winter 1988-89, Vol. XI, No. 2, pp. 222-239.

SMEEDING, T. and RAINWATER, L. (1991), "Cross-National Trends in Income Poverty and Dependency: The Evidence for Young Adults in the Eighties." LIS Working Paper No. 67.

SMEEDING, T., SAUNDERS, P., CODER, J., JENKINS, S., FRITZELL, J., HAGENAARS, A., HAUSER, R. and WOLFSON,M. (1993), "Poverty, Inequality and Family Living Standards Impacts Across Seven Nations: The Effects of Non-Cash Subsidies For Health, Education and Housing", Review of Income And Wealth (September 1993), pp. 229-256.

STIGLITZ, J.E. (1988), "Economics of the Public Sector". New York/London 1988.

TOWNSEND, P. (1985), "A Sociological Approach to the Measurement of Poverty: A Rejoinder to Professor Amartya Sen". Oxford Economic Papers, Vol.37, No.4, pp. 659-669.

TOWNSEND, P. (1987), "Deprivation". Journal of Social Policy 16.2, pp. 125-146.

VAN DER GAAG, J. and SMOLENSKY, E. (1982), "True Household Equivalence Scales and Characteristics of the Poor in the United States". Review of Income and Wealth, Vol. 28 (March 1982), pp. $17-28$.

WALKER, R. (1987), "Consensual Approaches to the Definition of Poverty: Towards an Alternative Methodology". Journal of Social Policy 16.2, pp. 213-226.

WOLF, W. (1988), "Verzerrungen durch Antwortausfälle in der Konsumerhebung 1984". ÖSTAT, Statistische Nachrichten, 43. Jg. 1988, Heft 11, pp. 861-867. 